\title{
The Political Economy of WAR ANd PeAce
}

\author{
Christopher J. Coyne and Adam Pellillo*
}

\begin{abstract}
From a political economy perspective, in order for conflict to occur, one (or more) political actor(s) must expect that the benefits of entering into conflict (e.g. improved security, political, social, or economic outcomes) exceed the costs. Understanding why this calculus would tip in favor of conflict is the central question in the study of the political economy of war and peace. This survey explores some of the institutional and political factors that set the underlying conditions for the emergence of conflict. The political economy perspective offered here differs from other important surveys and analyses of the same topic, which have focused on the ethnic dimensions of war (Horowitz 1985), the general causes and consequences of civil war and civil conflict (Sambanis 2002; Collier and Hoeffler, 2007; Blattman and Miguel 2010), and more general aspects of defense economics (Sandler and Hartley 2007).
\end{abstract}

\footnotetext{
* Christopher J. Coyne (ccoyne3@gmu.edu), Department of Economics, MSN 3G4 George Mason University, Fairfax, VA, 20020 and Adam Pellillo (adam.pellillo@mail.wvu.edu), Department of Economics, West Virginia University, PO Box 6025, Morgantown, WV 26506-6025.
} 


\section{Introduction}

Violent conflict is extraordinarily costly. Causing immense human suffering, loss of life, internal displacement, and destruction of resources, war is effectively 'development in reverse' (Collier et al. 2003). Given its social welfare consequences, the emergence of conflict should be seen as a puzzle to many observers. Yet from a political economy perspective, in order for conflict to occur, one (or more) political actor(s) must expect that the benefits of entering into conflict (e.g. improved security, political, social, or economic outcomes) exceed the costs. Understanding why this calculus would tip in favor of conflict is the central question in the study of the political economy of war and peace. Analyzing the logic of political violence requires the tools of public choice economics. By highlighting the incentives, opportunities, and constraints facing different political actors (e.g. leaders, rebels, military officers, insurgents, terrorists, diplomats, and even the occasional firm ${ }^{1}$ ), we can understand why conflict occurs. ${ }^{2}$ This approach to understanding war and peace places primary emphasis on the roles of constitutions, governance, legal systems, and bureaucracies since these institutional factors influence the incentives, opportunities, and constraints that political actors face. For instance, we consider why weak and ineffective political institutions may not provide binding constraints on the declaration of war or may insufficiently protect private property rights from expropriation. Further, weak legal

\footnotetext{
${ }^{1}$ Guidolin and La Ferrara (2007), for instance, find that the death of Jonas Savimbi, the UNITA rebel group leader in Angola, led to a decline in stock market returns among mining companies holding concessions in that country. They conclude that moderate levels of civil conflict can actually be financially beneficial for a handful of firms whose profitability is determined by the prolonging of conflict. This illustrates that some investors or companies may turn a blind eye to conflict given its profitability.

${ }^{2}$ As described by Acemoglu (2003, p. 621), under a theory of social conflict, "societies choose different policies, some of which are disastrous for their citizens, because those decisions are made by politicians or politically powerful social groups that are interested in maximizing their own payoffs, not aggregate output or social welfare." Tullock (2005: 312) argued that "it is clear that... an extremely bloody and destructive war and, looked at from the standpoint of the entire citizenry of the two countries, undesirable. Looked at from the standpoint of the dictator, however, it has a positive discounted value."
} 
institutions may preclude the resolution of disputes through legitimate means or may not impartially enforce contracts. Poor political institutions (or 'bad governance') can further hamper the ability of political actors to credibly commit to peace negotiations, providing a rationalist explanation for the emergence of conflict (Fearon 1995). Weakly institutional polities may not lead the true social costs of conflict to be internalized in the decision making calculus of political leaders. These factors set the underlying structural conditions that provide opportunities for expropriation and conflict.

While we cannot comprehensively assess all of the proximate causes of conflict in this chapter, our hope is to shed light on some of the institutional and political factors that set the underlying conditions for the emergence of conflict. ${ }^{3}$ This political economy perspective differs from other important surveys and analyses of the same topic, which have focused on the ethnic dimensions of war (Horowitz 1985), the general causes and consequences of civil war and civil conflict (Sambanis 2002; Collier and Hoeffler, 2007; Blattman and Miguel 2010), and more general aspects of defense economics (Sandler and Hartley 2007). Together, these surveys should help to illustrate the complexities of conflict while at the same time contributing to our understanding of its underlying causes.

\footnotetext{
${ }^{3} \mathrm{We}$ are cognizant that there are multiple factors not discussed in this chapter that are central to understanding war or peace. For instance, we exclude factors such as ethnolinguistic fractionalization (or polarization), the trade in small-arms, post-conflict economic reconstruction, the role of geography (e.g., terrain, natural resources, commodities, such as diamonds or cocaine, that fund rebels groups) that influence the onset, duration, and recurrence of conflict, as well as the industrial organization of terrorist, insurgent, and rebel groups, the influence of ideology or behavioral factors on the decision making of political actors. Our exclusion of these factors is not intended to downplay the importance of them for understanding conflict and peace. Instead, our central focus is on the institutions and political elements which influence the costs and benefits associated with these various factors. For instance, adverse geography and rough terrain can challenge the ability of states to establish monopolies on the legitimate use of force (see Acemoglu, Robinson, and Santos 2010). Likewise, natural resource rents could induce agents to choose to appropriate others' property rather than to engage in productive behavior.
} 
We proceed as follows. The next section briefly assesses the economic approach to conflict. We focus on different types of conflict and summarize the existing literature's approaches to conflict analysis. Section 3 discusses the importance of institutions for understanding conflict. After defining the relevant institutions, we explore the variety of channels through which institutions may influence war or peace. Most of the analysis in these sections focuses on intra-state conflict, given that this has become the dominant form of conflict in recent years (see Harbom and Wallensteen 2010). Our focus then largely shifts to the analysis of inter-state war and peace in Section 4. We first consider democratic peace theory in Section 4.1, followed by a consideration of the "capitalist peace" in Section 4.2. In each case we provide a discussion of the underlying theory, as well as the empirical evidence for and against each theory. Section 5 concludes with a discussion of potential avenues for future research and analysis.

\section{The economic analysis of conflict}

\subsection{Defining conflict}

Before discussing the political economy of war and peace, it is instructive to define 'conflict' and to list the various forms of conflict that have been observed over time and across countries. For our purposes, a conflict occurs when two (or more) parties resort to violence as a means of dispute resolution. Disputes can occur for a variety of reasons (e.g., over economic resources or opportunities; ideological, ethnic, or religious tensions; politics and borders). 
At the meta-level of analysis, an intra-state war is defined by the Correlates of War Project as a war that is fought within state borders between a government and a non-government entity (a civil war), or, alternatively, as a war between two or more non-government forces (an inter-communal war). Intra-state wars are associated with at least 1,000 combat-related deaths in one year (Small and Singer, 1982). An inter-state war is defined as a war between two states with at least 1,000 battle-related fatalities in total in a given year. Conflict can also be extrastate in nature. An extrastate war is one that is fought between a state and a non-state entity outside of the state's own territory (for instance, the conflict between Israel and the Hezbollah militia). Once again, to be classified as an extra-state war, there must be at least 1,000 battlerelated fatalities in every year. ${ }^{4}$ The Correlates of War Project has data available for wars that have taken place between 1816 and 1997, but the project team has recently added data up to 2007 in other datasets.

Another conflict dataset by the Uppsala Conflict Data Program and the Centre for the Study of Civil War at the International Peace Research Institute (UCDP/PRIO) similarly differentiates conflict along different dimensions (e.g. intra-state, inter-state, etc.). The $\mathrm{UCDP} / \mathrm{PRIO}$ definition of armed conflict is construed as those forms of political violence that are associated with at least 25 deaths in one year. ${ }^{5}$ Specifically, they define conflict as "a contested incompatibility that concerns government and/or territory where the use of armed force between two parties, of which at least one is the government of a state, results in at least 25

\footnotetext{
${ }^{4}$ The Correlates of War Project also has data available at the dyadic level (i.e. data for militarized interstate disputes and their locations), as well as information on national material capabilities, formal alliances, diplomatic exchange, etc.

${ }^{5}$ They also define civil wars (incidence of intrastate war) as those wars with at least 1,000 deaths in a single year.
} 
battle-related deaths (Gleditsch et al. 2002). ${ }^{6}$ The UCDP/PRIO Armed Conflict Dataset (ACD) covers wars and conflicts over the time period from 1946-2008.

As far as the prevalence of different types of conflict and political violence is concerned, incidents of intra-state conflict have far exceeded those of inter-state war in the past few decades. $^{7}$ As reported by the UCDP, there were 36 active armed conflicts in 2009-none of which were inter-state in nature (Harbom and Wallensteen 2010; see also Collier and Hoeffler 2004; Rocco and Ballo 2008). Indeed, in a recent survey regarding the theory and evidence on civil war, Blattman and Miguel (2010) report how common civil war is across countries. More than half of all nations have experienced a civil conflict, with 20 percent of countries experiencing at least 10 years of civil war since 1960 (Blattman and Miguel 2010, p. 4). In SubSaharan Africa, 29 of 43 countries have experienced civil conflict during the 1980s and 1990s (Miguel, Satyanath, and Sergenti 2004). ${ }^{8}$ Yet fortunately, since this time period, civil war has been on the decline (see Blattman and Miguel, 2010).

\footnotetext{
${ }^{6}$ Some conflicts may be difficult to code or define. When particular conflicts are coded differently, the empirical findings on conflict may lack robustness. As noted by Kalyvas (2007, p. 418), "coding decisions are crucial in determining the onset and termination of civil wars and distinguishing between a single ongoing but intermittent war or a succession of several distinct ones." As argued by Sambanis (2004), the Russian-Chechen civil war in the 1990s could be construed as a war of decolonization, for instance. In this chapter, we largely refer to the general term, 'conflict,' though differentiate this term when necessary.

${ }^{7}$ An unbundling of 'conflict' illustrates the variety of forms of political violence that have been observed over time: interstate wars, civil wars, terrorism, coups d'état, state-sanctioned violence and political repression, genocides, rebellions, social unrest and riots, insurgencies, guerilla warfare, covert operations, violence related to social fractionalization (e.g., along ethnic, linguistic and religious lines), military and diplomatic interventions, and drugtrade related violence (and more). After conflict and political instability often come efforts to reconstruct the economy (both indigenously and externally), demobilize, disarm, and reintegrate (DDR) former combatants, consolidate or fundamentally reform political institutions, provide health care and basic services to citizens, refugees, and internally displaced persons, prevent the outbreak of further conflict, and move towards a more stable and peaceful society.

${ }^{8}$ As succinctly described by Fearon (2007, p. 318), "the most common form of civil war in the post-World War II period has been a stalemated guerrilla war confined to a rural periphery of a low-income, post-colonial state."
} 


\subsection{Economic approaches to conflict}

The economic analysis of conflict largely began with the conflict models of Tullock (1980, 2005), Garfinkel (1990), Hirschleifer (1989, 1991, 1996), Grossman (1995) and Skaperdas (1992), though economists have long studied conflict and cooperation. In this section, we discuss some of the formal foundations put forth by economists by analyzing a model that specifies a choice over production or appropriation.

\subsubsection{Choice over production or appropriation: rent-seeking in the context of} conflict

One approach towards understanding conflict is to model it as a violent competition or contest for resources (be they in the form of rents, tax collections, land, or even political power). Hirschleifer $(1991,1996)$ models a choice between two different technologies that can be employed by political actors: a technology of production and a technology of appropriation, conflict, and struggle. ' 'Struggles' can be construed as rent-seeking, for instance, in the sense of Tullock (1967, 1980) and Krueger (1974), or as more violent conflicts for access to natural resources, such as crude oil and diamonds, or as opportunistic attempts to take advantage of power vacuums. ${ }^{10}$ This neoclassical approach to conflict involves solving constrained

\footnotetext{
${ }^{9}$ This choice over production or predation is by no meansabstract. Grossman and Kim (1996) note that the Vikings and the Mongols were almost entirely predatory in their economic activities. See also Olson (2000).

${ }^{10}$ Neary (1997) compares the properties of rent-seeking models and economic models of conflict, illustrating how both models describe the allocation of resources in pursuit of a fixed prize. Conflict models typically involve a higher level of expenditures on 'predatory' or 'appropriative' activities than do rent-seeking models, which is expected given the relative welfare costs of the two activities.
} 
optimization problems, as put by Hirschleifer (1996, p. 17), where "each competitor chooses a preferred balance of productive effort and conflictual effort" in order to determine the equilibrium outcome (if any exists).

In conflict models like Hirschleifer's, agents can divide their initial endowments between productive efforts $\left(\mathrm{E}_{\mathrm{i}}\right)$ or fighting efforts $\left(\mathrm{F}_{\mathrm{i}}\right)$ in order to maximize steady-state income $\mathrm{I}_{\mathrm{i}}{ }^{11}$ A probabilistic contest-success function, which determines the likelihood that a particular political actor will be victorious in political equilibrium (say political actor number 1), can be modeled as $\frac{F_{1}}{F_{2}}=\left(\frac{F_{1}}{F_{2}}\right)^{\mathrm{m}}$, where the relative price ratio on the left-hand side is referred to as the 'success ratio' and is a function of relative 'fighting efforts, $\stackrel{F_{1}}{F_{\mathbf{2}}}$, along with a 'decisiveness parameter,' $m$ (Tullock 1980; Hirschleifer 1989). ${ }^{12}$ When the decisiveness of conflict is low or the technology favors the agent investing in defensive resources, the stakes are small and peace will be more likely.

Similarly, Grossman and Kim (1996, p. 57) develop a model of interaction between 'predator' and 'prey,' where, given initial endowments, the predator 'allocates its resources to either the production of consumables, or to offensive weapons that the predator uses to appropriate the prey's property, or to both." The 'prey' agent can dedicate endowment resources to defensive fortifications or productive capital. Predators solve a similar problem, but instead of defensive fortifications they invest in offensive weapons. As put by Hirschleifer (1991), when

\footnotetext{
${ }^{11}$ In some instances, this is referred to as a split between 'guns' and 'butter', subject to a particular resource constraint (see Garfinkel and Skaperdas 2000).

${ }^{12}$ The probabilistic contest success function was first put forth by Tullock (1980). According to Garfinkel and Skaperdas (2000), the most commonly employed functional form of this contest success function in the literature is $p\left(S_{1}, E_{2}\right)=\frac{F_{1}}{F_{1}+E_{2}}$ where $p$ is the probability of success or is the proportionate share of the 'prize' won by a game's player.
} 
an individual's endowment is relatively small, the dominant strategy will be to shift resources toward predatory activities. This may explain why civil conflict and civil war typically occur in countries with low levels of economic growth and development.

These models illustrate the tradeoffs individuals face and how they may choose to allocate their resources in different contexts (e.g., when property rights are insecure or institutions impose weak constraints on political rulers). Yet there are limitations to this approach to explaining conflict (see, for instance, Gartzke, 1999 and Cramer, 2002). As noted by Blattman and Miguel (2010, p. 11), "one drawback of the typical contest model is that insurrection is never fully deterred; arming and fighting always occur in equilibrium. There is typically no decision to fight ... this prediction of ever-present conflict is unsatisfying since political competition over power and resources is ubiquitous while violent conflict is not." This highlights the importance of focusing on issues of weak governance, poor constitutional constraints, and other institutional factors that set the contexts for where, when, and how these types of conflict decisions are made.

\subsubsection{Greed vs. grievance}

Successful rebellion or insurrection typically is seen as a function of the resources or time devoted toward appropriative activities (see Grossman 1991). But it is also important to understand why rebellion occurs in the first place. Collier and Hoeffler (2004) discuss how political scientists usually attribute group "grievances" (along political, social, economic, or ethnic lines for instance) as the cause of most rebellions, whereas the economics literature (e.g., Grossman 1991) usually points to economic incentives (i.e., 'greed') and opportunities for 
appropriating wealth as the proximate cause. In testing the relative impacts of empirical proxies for 'greed' and 'grievance' on the risk of an outbreak of civil war, Collier and Hoeffler (2004) conclude that the 'greed' hypothesis is more strongly associated with the occurrence of civil war than indicators of grievance.

These empirical findings may explain why individuals with relatively low incomes choose to engage in conflict, as income opportunities in the marketplace may be few and far between relative to those in the 'conflict sector.' As an example of this way of thinking, Miguel, Satyanath, and Sergenti (2004) cite the description of a Liberian warlord provided in Brabazon (2003, p. 12): "Essentially, [Sekou Conneh, a rebel leader] is a businessman, not a soldier or a politician.... Occasionally he seems to remember that he should say something politically relevant and will make a short impromptu speech about the struggle for democracy and the freedom of the Liberian people." As reported by Hegre, Ostby, and Raleigh (2009), civil war in Liberia often took place in areas that were relatively wealthier, which they interpret as providing support for 'opportunity' explanations of conflict. ${ }^{13}$

On the other hand, a greater statistical emphasis on the 'greed' hypothesis of conflict does not necessarily imply that 'grievances' do not matter for conflict or rebellion. In other forms of conflict (e.g., terrorism and insurgencies), perceived grievances can motivate individuals to take up arms against the state or their fellow citizens. In fact, there is likely to be an interaction of the two, as was suggested by Jackson (2002) in his analysis of the Lord's Resistance Army in Northern Uganda. In other words, the dichotomy between 'greed' and 'grievance' may be less relevant than the combination of the two forces as propellants of

\footnotetext{
${ }^{13}$ The literature on terrorism, by contrast, suggests that the leaders of such groups tend to be young and highly educated (see Pape 2005 and Shughart 2011).
} 
conflict. Further, 'grievances' can turn into 'greed' as the course of conflict between the rebel group and the government proceeds.

The decision to appropriate someone else's assets is also likely to be a function of the constraints imposed by existing institutions. As far as political rulers are concerned, when faced with institutional constraints on appropriation (such as "independent" judges, legislators, bureaucrats, regulators, and a free media), the probability of theft is quite low. Individual nonstate agents (e.g., warlords, rebels and insurgents) seeking to appropriate other's property, likewise are constrained by existing political and legal institutions. Thus, as this logic suggests, the relative payoffs for appropriation and production are likely to be functions of the quality of a country's political and legal institutions - what is now commonly referred to as "good governance." This line of reasoning points to the conclusion that while rebels may indeed be motivated by "grievances" against the state, the underlying cause may be the absence of economic opportunities for improving their standards of living, resulting from insufficient protection of property rights, endemic government corruption or weak state capacity. ${ }^{14}$ This is the topic of the following sections.

\footnotetext{
${ }^{14}$ As argued by Sobek (2010, p. 267), “...states have the ability to address the demands of their citizens in ways that reduce the incentive for political violence, which limits the ability of rebels to overcome the problems with collective actions...strong states can [also] simply deter resistance through their ability to physically coerce dissenters." Thies (2010, p. 322) argues that "the incentive to rebel is a product of the probability of victory and the state's capacity to defend itself" and this is largely a function of its ability to extract tax revenues. Basuchoudhary and Shughart (2010) emphasize the role that economic liberty plays in reducing terrorism in societies characterized by ethnic tensions.
} 


\section{Institutions and Conflict}

In the sections below, we first discuss economic perspectives on conflict to illustrate why a game theoretic analysis of conflict hinges on the payoffs provided by existing institutions. We then discuss how institutions emerge, the roles of the state, and the structure of political institutions across countries. Along with these factors, we assess how institutional issues, such as credible commitment problems, and the consequences of different structures of institutions, such as low levels of economic development, influence variation in the likelihood of conflict across countries.

\subsection{The rationalist approach to conflict}

The immense economic and social consequences of violent conflict are well-evident. However, conflict still occurs, suggesting that some political actors gain (or expect to gain) from the initiation or prolonging of conflict. According to this view, political agents may view war "as a costly but worthwhile gamble" (Fearon 1995, p. 383). For instance, rebel groups or insurgents may continue to engage in civil violence as a means of achieving political control, influencing political outcomes or achieving other economic benefits, even though their actions generate significant externalities for others. Indeed, as argued by Tullock (2005, p. 311), "gain (or avoidance of loss) is the common reason for undertaking warfare." Political rulers - justly or unjustly - may declare war on other countries or move to repress particular groups within their own countries. 
Yet conflict poses an inefficiency puzzle: if there is a dispute between two (or more) agents, and all agents realize that the ex post costs of conflict exceed the benefits, then a Coasestyle bargain prior to conflict would make both parties strictly better off (see Powell 2006). Fearon (1995) argues that the "ex post inefficiency of war opens up an ex ante bargaining range" such that there should exist a set of Pareto-improving agreements that make both sides strictly better off. Yet there are reasons that these bargains do not occur. Fearon points to asymmetric information, commitment problems, and issue indivisibilities (e.g. on the basis of religion, ideology, ethnic or regional identity, etc.) that preclude compromise between disparate agents as plausible rationalist explanations for the breakdown of negotiations and bargaining.

Additionally, it is likely that one political actor's expectations of the costs and benefits of engaging in conflict are not aligned with another political actor's expectations. ${ }^{15}$ But it is also likely to be the case that the expected costs and benefits from the perspective of a political actor are not in line with the overall social costs and benefits. This may be because some political leaders do not internalize the full social costs of conflict, seeing only the benefits of maintaining political power, for instance. ${ }^{16}$

\footnotetext{
${ }^{15}$ Consider, for instance, the legal literature on the decision to settle or litigate. Two (or more) parties will end up in court if the parties have different expectations of the costs and benefits of doing so (see Landes 1971, Gould 1973, Shavell 1982). Analogously, in the context of conflict, two (or more) parties may end up in conflict based on differing expectations.

${ }^{16}$ Nevertheless, bargaining does occur between political actors. Peace treaties are often brokered and negotiations can occur after rounds of conflict (or even prior to the onset of conflict). Consider Lee's (1988) 'paid-rider' framework, where the state offers sanctuary to a terrorist organization so long as the group does not strike civilian or government infrastructure or buildings. This bargaining equilibrium has been realized in some contexts, like Germany's provision of refuge to the Red Army Faction (Baader-Meinhof Gang) in the 1960s (Shughart 2006), France's offer of sanctuary to Arab and Basque terrorists (Lee 1988), or, perhaps more poignantly, Afghanistan's preferential treatment of Al Qa'eda in the 1990s and early 2000s.
} 


\subsection{What are institutions and why do they matter?}

Many of the potential covariates of conflict (e.g., low levels of economic development, the effects of ethnic fractionalization or polarization, etc.) as well as the ability to credibly commit to peace negotiations or communicate with socially distant individuals are likely to be endogenous to a country's institutions. For instance, it has been noted empirically that countries with institutions that protect private property rights are associated with greater levels of economic development (Acemoglu and Johnson, 2005). Fearon and Laitin (1996) argue that formal and informal institutions usually preclude conflict between disparate agents, illustrating why ethnic fractionalization, for instance, is likely to be the result of an endogenous process (see also Easterly 2001 and Leeson 2005, who discuss why fractionalization may be endogenous to political and legal institutions). It is therefore important to understand the mechanisms by which variation in institutions across countries can be associated with variation in the likelihood of conflict.

But what are institutions and, more importantly, how can they affect the incidence of conflict? Institutions, as defined by Nobel Laureate Douglass North (1990, p. 97), are the "humanly devised constraints that structure political, economic, and social interaction." Institutions can emerge from a long run evolutionary or spontaneous process or they can be designed or imposed by external actors, as in the cases of colonial design of constitutions, country borders, and social institutions, post-World War II Japan and Germany, or more recently, in the cases of Afghanistan and Iraq. Formal institutions take into account the codified customary rules, constitutions, legal and political structures (e.g., bureaucracies, judiciaries and 
legislatures) that govern society. ${ }^{17}$ In the context of conflict, institutions can act as constraints on forms of political violence. As expressed by Fearon and Laitin (1996, pp. 717-718), "a great variety of human transactions and interactions involve the possibility of opportunism-selfinterested behavior that has socially harmful consequences... [I]f unchecked by formal or informal institutions, the expectation of such opportunism leads individuals to avoid interactions or to take costly actions to protect themselves in them, making for a 'society' of fear, poverty, and disorder." This makes highly relevant the choice between conflict and appropriation discussed in the above section.

The role of institutions, in this sense, ultimately is related to the potential problem of social order under a natural state of anarchy. "Good" institutions would be those that facilitate communication, coordination, the accurate formulation of expectations, and cooperation between disparate groups or agents and preclude violent conflict from emerging. Likewise, good institutions would enforce commitments between competing groups, either on part of the government or a rebel or insurgent group. When formal and informal institutions fail to act as binding constraints or engender preferences and incentives for appropriative activities, then conflict is more likely. Why may these institutions fail to prevent conflict?

\subsection{The role of the state and institutions}

One of the most fundamental roles of a legitimate state is to protect its residents from expropriation and violent coercion by others (Buchanan 1975). In other words, the legitimate

\footnotetext{
${ }^{17}$ Informal institutions, which are largely unconsidered in this survey, similarly govern political, economic, and social interactions but are not codified in any formal or legal sense. These informal institutions include such things as norms, conventions, social capital and religious practices (see Williamson 2000).
} 
domain of any government is to ensure the rule of law, peace, and prosperity. ${ }^{18}$ In general, the state fails to do so when there is a non-state or extra-state actor that engages in violent conflict against the state or its citizens as a means of appropriating resources, achieving political power, or pursuing other ends. In the Weberian sense, when this occurs, the state's monopoly on the legitimate use of force is challenged by another entity.

Yet the government itself can also expropriate the wealth of its citizens and deny them fundamental human and civil rights. Ensuring that political actors do not expropriate the property of their residents, for example, or engage in a bellicose foreign (or domestic) policy requires the imposition of political and legal institutional constraints (e.g., checks by the judiciary, the legislature, or a free press) on the political elite. Yet endemic corruption, kleptocracy, ethnic favoritism, embezzlement, and nepotism can also spark conflict along both 'greed' and 'grievance' lines.

Unfortunately, first-order institutional arrangements are largely absent in many countries. Countries with poorly developed political institutions-even those with the trappings of democracies (e.g. elections, parliamentary representation, etc.)—can experience conflict. As discussed below, these types of political institutions (i.e., anocracies) experience a disproportionate number of conflicts, which suggests that it may not be democracy per se that inhibits conflict, but other institutional factors such as overall state capacity.

Why are the institutional conditions (e.g., private property rights, accountability and transparency in government, and the freedom of citizens to voice their grievances through peaceful political processes, etc.) that would lead to cooperation instead of conflict not

\footnotetext{
${ }^{18}$ In the United States, for instance, as noted by Tullock (2005, p. 16), "the police and the courts stand ready to use violence against anyone who attempts to take your property." It is not the case that such legal institutions actually lead to the application of violence, yet moreover it is the credibility of the threat to use violence that motivates action.
} 
established ${ }^{19}$ In order to answer this question, we must discuss where institutions come from in the first place.

As put by Olson (2000, p. 1), "In a Hobbesian anarchy, where there is no restraint on individuals' incentives to take things from one another, or in a kleptocracy, where those in power seize most assets for themselves, there is not much production or many gains from social cooperation through specialization and trade." Buchanan (1975) argued from a contractarian perspective, that individuals would see it as mutually advantageous to impose binding constraints on their own behavior in order to shift efforts from appropriation in the natural state of anarchy to production in a constitutional form of government. Similarly adopting a contractarian view of the state, Nozick (1974) held that we should expect to see a single political entity emerge from a natural state of anarchy with a monopoly on the legitimate use of force owing to the benefits of specialization, division of labor, and economies of scale. Competing protective agencies would presumably strike bargains to combine their efforts in protecting citizens and maximizing long term tax revenue. While the dynamics described in the contractarian perspective could lead to first order constitutional orders and classically liberal political and legal institutions if implemented in practice, casual empiricism suggests that this has not occurred in many countries. ${ }^{20}$ There is remarkable variation in the quality of institutions across countries as well as in the efficacy of these institutions in constraining political actors to do what Nozick and Buchanan envisioned they should do: provide security of person and property for citizens. ${ }^{21}$

\footnotetext{
19 As argued by Shughart (2006, p. 8), terrorism, for instance, is largely a function of "cartographic and constitutional failure."

${ }^{20}$ As discussed by Skaperdas (1992, p. 720), "unlike the competitive paradigm or the state of nature, property rights in actual societies are incompletely specified and enforced, and social norms or shared ethical beliefs, which could serve the same function, do not cover every contingency."

${ }^{21}$ Ideally, as Holcombe (2008, p. 15) writes, "because government receives its income from the productivity of its citizens, government has an incentive to protect its tax base, and produces national defense to do so. Citizens also
} 
A more empirically realistic constitutional equilibrium is one based on relative bargaining strength. $^{22}$ At the time that legal institutions and political structures are agreed upon or imposed, they are not necessarily based on mutually advantageous exchange but the relative political power of particular political actors. For instance, consider that Acemoglu, Johnson, and Robinson (2001) find empirical support for the hypothesis that the institutions imposed by colonial rulers and settlers hundreds of years ago have influenced variation in economic outcomes across countries in modern times. When those initial institutions were meant to be extractive in nature in order to benefit these political actors with relatively greater bargaining strength (colonists), they may not have adequately constrained the ruling political elite from expropriating ordinary citizens' property. Many of the constitutional structures we observe today are moreover a result of colonial planning or exogenous imposition and less so a result of the indigenous development of context-appropriate and mutually-agreed upon political, legal, and economic institutions. Consider that many countries (and country borders) in Central Asia, the Middle East, and Sub-Saharan Africa were all created by colonizers (see Shughart 2006), many of whom knew little about the political, social, ethnic, and cultural dynamics of these countries.

Olson (2000) illustrated that the development of political, fiscal, and legal institutions can be an indigenous process as well. From a state of anarchy, when political actors are provided with a monopoly of coercion over a particular area, the incentives they face may lead them to transition from 'roving banditry' to 'stationary banditry.' Instead of asset expropriation or confiscatory tax rates, these political actors may slowly lower their tax rates to encourage more

benefit from being protected from outside predators, having only to give a limited portion of their resources to the inside predator: the government."

${ }^{22}$ See Holcombe's (1994, Chapter 2) economic theory of rights. Bargaining power, he claims, can be a result of economic resources or military prowess. 
production. Over time, they implement the tax revenue-maximizing rate, effectively becoming Leviathans. $^{23}$ Through the course of time, stationary bandits would have an incentive to provide public goods (such as security) in order to expand the tax base. This development of political, legal, and fiscal institutions does not occur by social contract or voluntary exchanges, however, which contrasts rather sharply to the contractarian views described above. Institutions, it is taken, are largely a result of the demand for the largest tax base as possible by stationary bandits. $^{24}$

In observing political and legal institutions across countries today, we find that many states still do not provide sufficient protection or enforcement of property rights, largely because the political actors in those countries are still insufficiently constrained. This suggests that variation in conflict across states may largely be a function of long run historical processes. ${ }^{25}$ In this sense, political and legal institutions are largely inefficient due to the relative bargaining power of political actors (see also Acemoglu 2003). As an example of constitutional constraints in the context of inter-state conflict, with weak constitutional constraints on bellicose foreign or domestic policy decisions, political leaders can initiate conflict with other countries with relative

\footnotetext{
${ }^{23}$ In other words, “...the stationary bandit, because of his monopoly on crime and taxation, has an encompassing interest in his domain that makes him limit his predations because he bears a substantial share of the social losses resulting from these predations" (Olson 2000, p. 9).

${ }^{24}$ As argued by Olson (2000, p. 25), "To reach the maximum income attainable at a given tax rate, a society must enforce contracts (including those involving long-term loans) impartially, but the full gains are again reaped only in the long run." All of this also suggests that leader time horizons and time preferences also matter for the onset of conflicts. Olson wrote (2000: 26) "at the limit, when an autocrat has no reason to consider the future output of a society, his incentives are those of a roving bandit, which is, in effect, what he becomes."

${ }^{25}$ This line of reasoning also suggests that both historical and current institutions can be somewhat endogenous to political actors, which makes the institutional analysis of conflict more complex. As noted by Weingast (1997), the rule of law must be self-enforcing, as political leaders can reduce the efficacy of political and legal institutions through their actions.
} 
ease. Conversely, with relatively strong constitutional constraints, political leaders face more difficulty in initiating conflict with other countries. ${ }^{26}$

As an example of these constraints, Choi (2010, p. 442) discusses the role of legislative 'veto' players, arguing that, "it is reasonable to assume that the president is less likely to start or continue a war if he or she foresees mounting difficulties from legislative veto players capable of restricting, redirecting, and terminating military operations." Choi’s (2010) empirical findings suggest that legislative constraints on executive authority (across all dyads, or pairs of nations) are indeed associated with a lower probability of the onset of a militarized interstate dispute (MID), except for those dyads that are autocratic. ${ }^{27}$

\subsection{Weak state capacity}

Huntington (1968, p. 1) argued that "the most important political distinction among countries concerns not their form of government but their degree of government." State capacity can be conceptualized as a function of military power, bureaucratic and administrative quality, and political institutions (see, for instance, Hendrix 2010). ${ }^{28}$ Military power, Hendrix (2010, p. 273) argues, is part of the classical Weberian view, which maintains that the state "claims the monopoly of the legitimate use of force within a given territory." Strong military power (using military expenditures per capita as a metric) is usually associated with a reduced risk of conflict,

\footnotetext{
${ }^{26}$ As we discuss below in the section on democratic peace theory, mass public opinion can also influence whether war is declared.

${ }^{27}$ Other institutional examples stem from the economic analysis of terrorism. Basuchoudhary and Shughart (2010) find that institutions that promote economic liberty are actually more effective at precluding terrorism in societies characterized by ethnic tensions than political institutions that afford protections to individual rights.

${ }^{28}$ Yet the issue of 'state capacity' is closely related to institutions as far as the determinants of conflict are concerned. 'Weak states' can be thought of as byproducts of weak institutions, since institutions (e.g., formal institutions, such as constitutions) delineate the constraints faced by political agents and likewise influence the incentives and opportunities these agents have.
} 
as well as shorter conflict durations. ${ }^{29}$ As put by De Soysa and Fjelde (2010, p. 288), "if states have onsets of civil war, then by definition, a state is unable to monopolize the use of force." Skocpol (1985) argues that state capacity is defined by sovereign integrity, the level of financial resources (e.g. the tax base), the loyalty and skill of officials, the stability of administrativemilitary control, and the ability to employ resources (e.g. public goods provision).

As noted by Sobek (2010, p. 267), "by increasing the value of the status quo, [more capable] states make it more difficult for the prospective rebels to organize....[S]trong states also have the ability to deter potential rebels through the threat, or actual use, of physical coercion, which essentially lowers the probability of rebel success." Since strong states are characterized by institutions that constrain rulers and protect property rights from internal and external expropriation, it is likely that the same strong institutions also lead to high levels of income per capita, creating a problem of endogeneity in identifying the causal mechanism. ${ }^{30}$ Dissident groups in high-income states likewise are constrained by the greater opportunity costs of forgoing productive activities in lieu of producing dissent or violence. Then again, Sobek (2010, p. 267) argues that "in higher capacity states, however, the increase in poverty may have no impact, as the state can either enact policies to alleviate the poverty or deter actors from escalating the conflict to a civil war."

\footnotetext{
${ }^{29}$ Regardless of the state's relative military capacity or strength, however, the tactical abilities of insurgents can lead to protracted civil conflicts. Consider historical examples of the Palestine Liberation Organization (PLO), the Viet Cong, the Irish Republican Army (IRA), Spain's Euskadi ta Askatasuna (ETA) or more recent examples of insurgents in Afghanistan and Iraq, where relatively strong states with superior military capacity (i.e. superior technology, better-trained soldiers, etc.) have not been able to fully counter insurgencies. As summarized by Shughart (2006, p. 21), “...relatively small groups of urban guerillas, though overmanned and outgunned by regular armies on the ground, can demoralize great empires by waging campaigns of carefully planned attacks on targets inevitably left pregnable by the larger, but less flexible forces arrayed against them." On the other hand, the relative strength of the state in these circumstances may have prevented terrorist or insurgent momentum from snowballing into full rebellions and intra-state wars.

${ }^{30}$ A strong military can also constrain decision making on the part of the political leadership in autocracies. As noted by Tullock (2005, p. 48), "[The dictator] is surrounded by a large number of people, and if he succeeds in either annoying them or giving them the impression that he is weakening, he will probably be removed."
} 
Empirically, Fearon and Laitin (2003), adopting low income per capita as a proxy for state capacity, find support for the hypothesis that intrastate conflict typically is associated with weak states. Braithwaite (2010) finds that countries with relatively higher levels of state capacity are better able to resist the possibility of violence spreading from one conflict-torn country to another. Weak state capacity is also likely to be associated with the anti-colonial nationalist movements and ethnic separatist movements that took place after World War II (see Shughart, 2006, p. 17). ${ }^{31}$

\footnotetext{
${ }^{31}$ Note that we do not consider in this section whether a strong, overarching state is actually preferred from a social welfare perspective. Weak states are associated with conflict, yet this may be because the legitimacy of the state is questionable or because the political elite seek to impose its will on groups within its country that would prefer autonomy or independence. Allowing for full autonomy of different ethnic or political groups may be optimal from the perspective of social welfare. Though, of course, this is unlikely to be compatible with the incentives of government officials in central governments, particularly when tax bases and the revenues from resource sales are at stake.
} 
Thies (2010), however, finds that state capacity is endogenous to the onset of civil war, and in using a simultaneous equation model, it appears that state capacity does not have a significant effect on the likelihood of conflict. Theory supports both directions of causation. Consider that Besley and Persson (2009) develop a model that illustrates why prior external wars may have led to the development of income tax systems and the building of state capacity. Their empirical specifications highlight that a country's incidence of external conflict up to 1975 has a positive impact (statistically and economically significant) on an array of measures of fiscal capacity (e.g. share of taxes in GDP, one minus the share of trade taxes in total taxes, etc.).

\subsection{Political institutions and civil conflict}

It is instructive to disaggregate 'political institutions'-e.g., democratic regimes, autocracies, and military juntas, etc. - in order to understand the causal mechanisms by which they influence conflict and cooperation. ${ }^{32}$ Elbadawi and Sambanis (2002) find that democracy is associated with a lower incidence of civil war. This is logical considering that consolidated democratic institutions are likely to lead to the avoidance of conflict for a number of reasons. As expressed by Skaperdas (2003, p. 137), "Modern governance ... with [its] patchwork of checks and balances, wider representation, professional bureaucracies, and loyalty to nation states has managed ... to overcome some of the most damaging aspects of appropriation and conflict. Fighting in the battlefield has been supplanted in most cases by fighting in courts and the halls of parliament." Democratic political regimes typically ensure accountability, transparency, and

\footnotetext{
${ }^{32}$ While a detailed discussion of the characteristics of these different political institutions is beyond the scope of this survey, a consideration of some of the relevant literature's empirical findings shed light on the relationship between institutional quality and the incentives for conflict versus cooperation.
} 
binding constraints among political actors, as well as the ability for individuals to redress grievances or settle disputes by accessing legal institutions.

Further, facing the electorate periodically induces political rulers to support policies that are preferred by the median voter. This ensures that when political power is vested in the general populace, the likelihood of conflict will be lower. ${ }^{33}$ Many of these factors have been identified as reasons for why democracies seldom engage in war with one another (see the section below on the democratic peace hypothesis). On the other hand, the level of economic development in a country has been shown empirically to dominate the level of democracy as a predictor of the onset of conflict (Fearon and Laitin 2003; Fearon 2007). These findings suggest that the level of the development of democratic institutions in a country may be less important than the protections accorded to private property rights (see also Basuchoudhary and Shughart, 2010, in the context of transnational terrorism).

Political scientists have suggested that 'anocracies,' or quasi-democratic political regimes, experience a greater incidence of civil wars than their democratic or autocratic peers. As Hegre et al. (2001, p. 33) point out, "harshly authoritarian states and institutionally consistent democracies experience fewer civil wars than intermediate regimes." This implies that there is an inverted, U-shaped relationship between the incidence of conflict when distributed along an authoritarian-democratic spectrum, peaking with regimes that allow for dissent and rebellion, but which lack either the military or legal prowess to address it. Hegre et al. (2001, p. 33) argue that

\footnotetext{
${ }^{33}$ Yet, then again, elections sometimes can actually lead to conflict. Consider that in the 1991 legislative elections in Algeria, for instance. The Islamic Salvation Front (FIS) was voted into power yet the Algerian government responded by negating the electoral outcome, which subsequently contributed to a devastating civil war that resulted in the deaths of more than 120,000 individuals (Wantchekon 1999, p. 246). This doesn't necessarily undermine the argument presented above, but does offer an example of why elections must be compatible with the incentives and constraints faced by status quo political actors. Ethnic fractionalization can also drive electoral results, leading to the view that elections can be nothing more than an "ethnic census" (Horowitz, 1985; Kimenyi and Romero 2008, p. 8). The main findings of Coyne (2008) and Basuchoudhary and Shughart (2010) suggest that 'democracy' is oversold as a solution to intrastate conflict.
} 
anocracies are partly open yet also are partly repressive, resulting in a political equilibrium that "invites protest, rebellion, and other forms of civil violence.... [S] uch institutional contradictions imply a level of political incoherence, which is linked to civil conflict." Interestingly, their results suggest no difference in the probability of experiencing a civil war between countries they classify as strong democracies or as harsh autocracies.

\subsubsection{Regime uncertainty or instability}

Political regime change is often associated with civil war (see Hegre et al. 2001). Cederman, Hug, and Krebs (2010) find that changes in political institutions-both democratization and autocratization - are associated with greater incidence of civil war. However, when a transition to democratic rule creates popular unrest, civil violence tends to materialize more quickly, often taking the form of a coup d'état, than when nations move in the opposite direction. Thus, they find that democratization's influence on civil war comes sooner than that of autocratization. Irregular, unexpected changes in political leadership also are associated with greater risk of civil war onset (Gleditsch and Ruggeri, 2010).

Jones and Olken (2009) find that successful assassinations of national leaders can intensify existing moderate-level conflicts, though they can also lead to the end of intense ongoing war. Perhaps most importantly, they put forth evidence that successful assassination of autocrats can induce political regime transitions toward democracy. They conclude that "individual autocrats are cornerstones of national institutions..." (Jones and Olken, 2009, p. 85), which suggests that institutional change (and institutional quality) is subject to the incentives of the political elite. 


\subsubsection{Political repression}

Is political repression a cause of conflict? State repression or endemic corruption could prospectively catalyze the creation (or strengthening) of insurgent groups, rioters, terrorists, and others that oppose the ruling political elite. Yet state political actors could also ruthlessly suppress dissent, preventing any form of conflict from emerging in the first place. As noted by Fielding and Shortland (2010), pressure by security forces can disorganize insurgent groups and deter future protests or riots, yet a crackdown can likewise lead to the escalation of conflict, resulting from the repression of civil rights, and the interference with ordinary daily life, which produce a civilian backlash against the state. As noted by Shughart (2006), when state capacity is sufficiently strong to deter any form of conventional war-i.e. the state has well-equipped militaries, for instance, that preclude intra-state war from emerging - then terrorism may become the strategy of choice for those seeking political change through the application of violence.

Rocco and Ballo (2008, p. 348) define a repressive action as one that is "aimed at weakening opposition in order to reinforce the government's position.” Repression effectively reduces the opposition's political and/or economic rights (ibid, p. 355), but its effects may also spill over to innocent bystanders. Provocation is "a repressive action that reduces the opposition's status quo utility to the point of making the risks and the costs of a war worthwhile, since the war gives it an opportunity to overthrow the ruler and stop the repression." The probability of provocation is greater if "the rent a ruler can extract from his status is high and if the regular army is sufficiently effective." They list a series of civil wars in Africa that were triggered by government provocation, citing examples such as Algeria (in 1992, an anti-Islamist took control of the government, outlawing the dominant Islamist group, FIS, and reversing the 
electoral outcome), Rwanda (the Rwandan army's massacre of civilian Tutsis), and Sudan (the imposition of Islamic Shar'ia law).

Empirically, it appears that anocracies - the semi-democratic political regimes discussed above - also face a relatively high probability of political repression (see Regan and Henderson, 2002). This is peculiar considering that conventional wisdom would suggest that autocratic governments should be more repressive. Regan and Henderson (2002, p. 133) argue that the inverted U-shape relationship they estimate between regime type and political repression is observed because "demands in a highly autocratic society will in effect be muted by fear of retribution, while demands in a highly democratic society will be channeled politically."

As Fearon (2004) finds, wars that originate in coups d'état or revolutions usually are short in duration because the 'technology' for acquiring state power hinges on rapid defections from within the state's military or security apparatus. Conversely, insurgencies may last much longer, as each insurgency's success or failure depends upon either a military victory or a negotiated settlement.

Leaders may engage in conflict because they are seeking to maintain or consolidate their power. As Rocco and Ballo (2008, p. 348) argue, nondemocratic government leaders will seek to reduce their risk of facing a coup d'état or political revolution by either bargaining with the coup's leaders (see Azam 2006; Azam and Mesnard 2003) or repressing the insurrection. Repression may be intensified to such a degree that it provokes a rebellion/revolt or even civil war.

Why would a political leader seek to foment unrest to such a degree that a civil war is provoked? Rocco and Ballo (2008, p. 354) construct a model where the incumbent government receives a rent from being in power yet faces the risk of being overthrown by another group. 
Without political power, there is no rent for rulers. To secure political power, therefore, the rulers in government may repress their citizens. Yet too much repression can foment revolt, leading to civil conflict. However, this may not necessarily be a bad thing from the perspective of the government if the probability of victory is greater than the probability of remaining in power peacefully. The government's probability of victory is a function of the relative effectiveness of the government and rebel armies. ${ }^{34}$

Ultimately, Rocco and Ballo's (2008, p. 360) model illustrates that "war is more likely when the government suffers from high political risk, when the rent from power is high and when the regular army is quite effective.... [G]overnment beliefs about the probability of an accidental revolt and the possibility of foreign intervention affect the costs and benefits of provoking a civil war."

\subsection{Credible commitment problems}

A credible commitment is defined here as the ability for one political actor or group to be timeconsistent with respect to peace negotiations, statements of intent, and willingness to respect and to enforce agreements or treaties. Time inconsistency, conversely, occurs when political actors have incentives to renege on previous commitments or statements of intent and contracting is therefore incomplete in equilibrium. ${ }^{35}$ These incentives can be structural in nature (e.g., due to political imperatives or optimal military strategies) or can be the result of behavioral aspects and leader characteristics (e.g., impulsiveness or time-inconsistent preferences).

\footnotetext{
${ }^{34}$ See Tullock (2005), who specifies more fully the probabilities associated with rebellions, coups, and other forms of political violence.

${ }^{35}$ Kydland and Prescott (1977) first identified the credible commitment problem that arises from time inconsistency among political leaders in the context of dynamic economic planning.
} 
With respect to the former, if a chief executive's prior agreement to end a conflict or not to initiate one are not enforced by the judiciary, legislature, media, or other third parties (such as supranational entities like the $\mathrm{UN}$ ), then a commitment to peace negotiations may be less credible. Political rulers may signal a willingness to commit to a peace agreement, but then realizing the gains from reneging on that agreement (e.g., preemptive military actions that shock one's adversary or marshal domestic political support), they may very well do so. The inability for political actors to credibly commit to peace negotiations may explain why contracts cannot be enforced between disparate, self-interested agents.

Credible commitments to negotiations or ceasefires truly matter for the emergence of a stable peace. As Leventoğlu and Slantchev (2007) discuss, most conflicts end with negotiated settlements. When commitments are non-credible, agreements are not binding. When this is the case, actors cannot be certain of the time consistency of prior negotiations, statements, or agreements, which influences their expectations of a peaceful negotiation in the future. Under such expectations, agents involved in conflict may not be willing or able to strike peaceful terms.

Sometimes a commitment problem can arise when two parties do not have recourse to a third party that is willing to enforce a peace treaty or other agreement. Credible commitment problems can also block the resolution of disputes between government agents and rebel groups. Empirically, policymakers' lack of credibility has been identified as a factor promoting insurgency (see Keefer 2008). The credible commitment problem also has been shown to be one of the causes of failed peace negotiations and the renewal of conflict. ${ }^{36}$ This being so, military victory by one side or the other may lead to a more stable peace after a conflict has ended (see Flores and Nooruddin 2009). Further, as DeRouen and Bercovitch (2008) find, conflict often

\footnotetext{
${ }^{36}$ This is because one episode of conflict reveals information about the relative military strengths of the parties involved. We discuss this in more detail in the subsequent sub-section on asymmetric information.
} 
resumes when civil wars end with negotiated settlements. Given that neither side may be able to commit to a peaceable resolution of a conflict, the actors involved in may have incentive to renew it.

As for theoretical inquiries into the credible commitment problem, Azam and Mesnard (2003) model a conflict between a government and an excluded group. Given the specific form of conflict technology, the excluded group is able to overthrow the government if it invests resources sufficient to overcome the government's expenditures on defense. To pacify the excluded group, the government offers a social contract that promises a wealth transfer to the group sufficient to mute the rebel's opposition. Yet in the absence of a credible commitment mechanism, the government would be forced to promise a larger transfer than otherwise in order to pacify the group (because the expected value of the promised transfer would be lower if there is a nonzero probability that the government will renege). If the transfer is too large, conflict is expected. $^{37}$ This illustrates why the level of credible commitment may be a significant explanatory factor in the observance of conflict. The absence of a credible commitment may help explain the inefficiency puzzle of war, i.e., why Pareto-improving agreements are not reached in the context of conflict, either beforehand or after it has started. As Powell (2006, p. 170) puts it, the incentives to renege on a previous agreement may "undermine the outcomes that are Pareto-superior to fighting," thereby leading to conflict.

What are potential solutions to the credible commitment problem? Given that poor contract enforcement is a hallmark of weak political and legal institutions, a Pareto-improving political transformation would be to implement ex ante binding constitutional constraints on

\footnotetext{
${ }^{37}$ Besley and Persson (2009) develop a model where there is an inability of a potential government to credibly offer transfers after conflict, in addition to the inability of prospective insurgents to credibly announce not enter into conflict.
} 
political actors to ensure the time consistency of policy. As Rocco and Ballo (2008, p. 364) argue, "a self-enforcing set of constitutional rules providing credible guarantees to the minorities would reduce both the opportunities for rent and political risk." As emphasized by Sobek (2010, p. 268), "highly capable states may be more able to win civil wars or more able to credibly commit to negotiated solutions."

\subsection{Asymmetric information}

Asymmetric information has been identified as one of the potential contributors to conflict (Fearon 1995). Initial differences in information sets may influence the expectations of the costs and benefits associated with entering into conflict or the expectations of probabilities assigned to victory, incurring physical harm, etc. (see Tullock, 2005, for example). This may be due to a misunderstanding of military capabilities (e.g., due to deliberate misrepresentation, ineffective intelligence gathering or lack of understanding of a political actor's intent). ${ }^{38}$ Differences in local circumstances and local knowledge can also affect the duration and termination of conflict. For instance, mountainous or cavernous terrain (e.g., Afghanistan), dense forests (e.g. Colombia, the DR Congo) and urban hideouts (e.g., Iraq) can provide safe havens for insurgents; counterinsurgency efforts may be stymied by the absence of critical information that may be learned only after boots already are on the ground. Asymmetric information may also lead to conflict because of linguistic fractionalization or misunderstanding of other's culture, conventions, intentions, and norms.

\footnotetext{
${ }^{38}$ Political actors may also have strategic incentives to misrepresent their intentions or hoard private information about their military capabilities. For instance, as discussed by Blattman and Miguel (2010, p. 16), "field generals have incentives to mislead civilian leaders about the capability of their military forces if they hope to keep the fighting going for longer than citizens would like (to keep military budgets at high levels, for instance)."
} 
However, asymmetric information cannot explain why civil conflicts continue or subsequently are resumed after one side has been defeated (Fearon 2004; Powell 2006; Blattman and Miguel 2010). Ostensibly, after the initiation of conflict, political actors can update their beliefs regarding their probability of victory after observing relative military strengths and weaknesses. The revelation of such information should open up a range of bargaining alternatives to conflict, though this may take a number of iterations of 'updating,' particularly when relative military strengths and weaknesses are in a state of flux due to external intervention, more troop deployments, or new developments of military technologies.

\subsection{Low levels of economic development}

Low incomes per person, negative income shocks, and slow economic growth have been identified as some of the most robust correlates of conflict, especially civil war (Collier and Hoeffler 1998, 2004; Sambanis 2002; Fearon and Laitin 2003; Blattman and Miguel 2010, pp. 3, 22). Poor countries experience disproportionately more conflict than their wealthier counterparts. As discussed above, a society's level of economic development is a function of its political institutions (see Acemoglu, Johnson, and Robinson 2001; Acemoglu and Johnson, 2005).

However, the relationship between conflict and low per capita incomes can go in both ways. As Blattman and Miguel (2010, p. 4) argue, "conflicts devastate life, health, and living standards"; thus it may well be the case that conflict is both induced by low incomes but conflict can also lead to lower rates of economic growth in the long run. The plausible endogeneity of economic growth and civil war has been noted by Sambanis (2004). Both hypotheses about 
causality are logically valid, especially considering that conflict can affect physical and human capital accumulation adversely. In order to isolate the effects of economic factors on the likelihood of conflict onset, Miguel, Satyanath, and Sergenti (2004) investigate the effect of negative economic shocks on the likelihood of civil conflict. Using the rainfall a region receives as an instrument for income growth, they find that reductions in annual economic growth increase the likelihood of civil conflict the following year.

Economic freedom is also associated with a lower likelihood of the onset of civil war (De Soysa and Fjelde 2010). Using the Index of Economic Freedom from the Fraser Institute, De Soysa and Fjelde find that this relationship is robust even when controlling for measures of government type (e.g., democracy, autocracy) and other commonly entered covariates (e.g., ethnic fractionalization, which is found to have a positive and significant influence - both statistically and economically - on the probability of conflict). In contrast to the results of Fearon and Laitin (2003) and Collier and Hoeffler (2004), they find that, other things being the same, per capita income isn't statistically significant (in either logged or lagged specifications).

\subsection{Institutions and Ethnic Tensions}

Empirical results regarding the role of ethnic tensions in conflicts have been mixed (Elbadawi and Sambanis 2000, 2002; Fearon and Laitin 2003; Collier and Hoeffler 2004; Sambanis 2004; Montalvo and Reynal-Querol 2005; Cederman and Giardin 2007; De Soysa and Fjelde 2010), mainly because of different functional forms and definitions of ethnic tension (i.e. 
'fractionalization,' 'polarization,' 'ethno nationalism'). ${ }^{39}$ In theory, the causation between ethnic tensions and formal institutions may move in both directions. Historical ethnic tensions may have influenced the development of political, legal, and fiscal constitutions, while formal institutions such as these may not have been sufficiently developed to coordinate behavior between disparate groups along more productive equilibria. In this sense, social fragmentation (e.g. ethnolinguistic ${ }^{40}$, religious, or regional fractionalization) may be endogenous to a society's institutions (see Easterly, 2000; Leeson, 2005). As described by Shughart (2006, p. 8), the creation of artificial nation-states at the Paris Peace Conference led to "some close-knit groups [being] divided by new, unwanted national borders; others were marginalized politically under governments controlled by irreconcilably different ethnic or religious factions." According to Elbadawi and Sambanis (2000), along with economic dependence on natural resources and poverty, failed political institutions are associated with a greater risk that of civil war in African nations. They (2000, p. 245) argue that "deep political and economic development failures-not tribalism or ethnic hatred — are the root causes of Africa's problems." As noted by Fearon and Laitin (2003, p. 88), civil wars "have structural roots, in the combination of a simple, robust military technology and decolonization, which created an international system numerically dominated by fragile states with limited administrative control of their peripheries." ${ }^{41}$

Take, for instance, the policies of Europe's African colonizers: colonial policies of indirect rule led to the division of indigenous peoples into privileged ruling groups and

\footnotetext{
${ }^{39}$ Empirical results do suggest that conflicts involving ethnic polarization, i.e., the 'sons-of-the-soil' wars, tend to last for relatively longer (see Fearon 2004).

${ }^{40}$ Many scholars define 'ethno-linguistic fractionalization' (ELF) as one measure of ethnic tensions in a society in accordance with the following Herfindahl-Hirschman index, widely adopted in the industrial organization literature as a measure of the size distribution of firms in a properly defined "market": $E L F=1-\sum_{i=1}^{n} s_{i}^{2}$ where $s_{i}$ is the share of ethnolinguistic group $i$ of all $n$ groups in a society.

${ }^{41}$ For a detailed analysis of how colonization led to weak state capacity and fragile states, see Shughart (2006).
} 
unprivileged 'ruled' groups (see, for instance, Shughart, 2006 and Mizuno and Okazawa 2009, p. 409). This likely had significant effects on postcolonial development in Africa, as "accountability of the government, democratic competition, property rights protection, prevention of corruption, and rule of law were lacking in many African countries [after independence], which made politics in African countries favorable only for narrow elite groups." The competition for resources that may occur between different ethnic groups may be the result of poor political and legal institutions. ${ }^{42}$ As Wood (2003) notes, political elites and political entrepreneurs can polarize societies along ethnic lines. ${ }^{43}$ Thus, a synthesis of these factors may be informative-weak political and legal institutions can endogenize the nefarious aspects of ethnic fractionalization (e.g., political power in the hands of one dominant ethnic group), and such poorly channeled ethnic fractionalization can lead to conflict.

\subsubsection{Issue indivisibilities}

Conflict may be due to 'issue indivisibilities' among political actors. When particular issues, such as religion (e.g., fundamentalists versus mainstream adherents), ideology (e.g., Maoist rebels), or liberal respect for human rights, are contested, there may be little room for peaceful compromise or dispute resolution (Fearon 1995). Bargaining may break down or not even begin. $^{44}$ With such beliefs and preferences, political agents can be obstinate at the bargaining

\footnotetext{
${ }^{42}$ See, for instance, Posner (2004).

${ }^{43}$ This can occur, for instance, through sheer political power or political disenfranchisement or even through the usage of propaganda (e.g., the role of Radio Télévision Libre des Mille Collines in the Rwandan genocide, where Yanagizawa (2009) estimates that nearly 45,000 Tutsi deaths can be accounted for due to this source of propaganda). See also Kirk (1983) and Glaeser (2005).

${ }_{44}$ As noted by Cowen $(2004$, p. 2), "Almost everyone wants peace on his or her terms, but for many sets of preferences the offer curves do not intersect... [S]ometimes the compensating variation will be infinite (or undefined) because the parties do not like the idea of paying cash for certain values, or do not like the idea of trading those values through a more complicated form of barter."
} 
table. $^{45}$ This is especially true when multiple actors are involved in a conflict and must necessarily agree on to settle their dispute (see Cunningham 2006).

Peter Bernholz (2006, p. 224) discusses how ideologies with "supreme values"-i.e., values that include an aim or bundle of aims that is strictly (or lexicographically) preferred to all others - can underpin terrorist activities. ${ }^{46}$ This observation is consistent with Rapoport's (1984) thesis that "doctrine is the ultimate source of terror." As summarized by Shughart (2006, p. 8), terrorism has occurred over time in waves of (1) ethnic separatism and national liberation (e.g., Algeria, Cyprus, and Israel etc.), (2) international-level ethno-national movements and left-wing terrorism (e.g., the Palestine Liberation Organization [PLO], the Euskadi ta Askatasuna [ETA], and Maoist or Marxist-inspired ideological groups, such as the Red Brigades and the BaaderMadoff "gang"), and (3) an Islamic movement to restore Caliphate hegemony and Shar'ia law through violence. The latter certainly is a matter of 'issue indivisibilities' that prevent bargaining solutions from being reached.

However, under particular circumstances (e.g., historical experiences or grievances, political disenfranchisement, ethnic favoritism, etc.) these 'issue indivisibilities' can be manifested in violent conflict. Group-based hatred can also lead to conflict in certain contexts (see Halperin 2008 for a discussion of the role of group-based hatred in the Israeli-Palestinian conflict). ${ }^{47}$

\footnotetext{
${ }^{45}$ Usher (forthcoming) makes the argument that economists have no theory for locating bargains on the contract curve in the Edgeworth-Bowley.

${ }^{46}$ Bernholz (2006) argues that terrorism based on such incompatible ideologies typically leads to fundamental social conflict. However, he also notes that such ideologies are not necessarily sufficient for terrorist activities to occur. Many individuals hold beliefs that are lexicographically preferred to other sets of values or aims (e.g., Jews, Christians, Muslims, Hindus and Sikhs), but we still observe peaceful coexistence among these disparate individuals and groups.

${ }^{47}$ As argued by Plaut (2004, p. 16) "When one is speaking of risks of national annihilation and genocide, decision making becomes lexicographic."
} 


\section{The Political Economy of Cooperation}

In the sections below, we will consider how two different institutions - one political and another economic - have contributed to the emergence and consolidation of peace across countries. This differs from the above analysis, which has mainly focused on the institutional factors that influence the onset of intra-state and extra-state conflict. First, we will discuss the democratic peace hypothesis, which sheds light on the politico-institutional determinants of cooperation across countries, and secondly we will assess the capitalist peace hypothesis, which says that the 'payoffs' from trade and exchange lead to the emergence of norms and conventions that likewise preclude conflict. Taken together, this institutional reasoning explains why, for the most part, peace prevails in the international arena.

\subsection{The Democratic peace theory}

\subsubsection{Background and Theory}

In the broadest sense, the democratic peace theory holds that democracies rarely engage in violent conflict with one another because of shared norms and the existence of political institutions which constrain the likelihood of conflict (see Russet 1993; Rosato 2011). The theory does not predict that democracies will never engage in violent conflict, but rather that they are less likely to do so against other democratic nations.

The democratic peace theory can be traced back to Immanuel Kant ([1795] 1983), who identified liberal constitutional republics as supplying one necessary condition for the emergence 
of "perpetual peace." In modern times, the democratic peace theory has played a central role in U.S. foreign policy (see Bennet and Ikenberry 2006) and is one of the theories of conflict most accepted by academics. Levy (1989, p. 270), for instance, writes that the democratic peace theory "comes as close as anything we have to an empirical law in international relations."48

The democratic peace theory is supported by two main propositions (see Gelpi and Griesdorf 2001; Rosato 2011). The first is that because of the development of informal institutions, such as social norms which foster liberal principles of respect, tolerance, and discourse, there is less to gain from resorting to violence (see Russett 1993; Dixon 1994; Weart 1998). To the extent that these nations share such democratic values, they are less likely to resort to violent conflict because they recognize mutual benefits from committing to peaceful dispute resolution. Doyle (1983a,b) and Russett (1993) extend the logic of norms to explain why democracies may be more likely to wage war against non-democracies. In the absence of shared norms, democracies cannot be confident that non-democracies will engage in peaceful dispute resolution.

A second proposition focuses on the nature of democratic political institutions. As discussed above, a key aspect of effective democratic politics is the existence of mechanisms that allow voters to monitor elected officials and to hold them accountable for their actions. Wherever such institutions exist, reelection-minded public officials generally will respond to the preferences of their constituents. In the context of international conflict, this point of view holds that public officials will resort to military force internationally only when domestic support for declaring war is adequate. The literature has identified in that regard, including the general

\footnotetext{
${ }^{48} \mathrm{We}$ should also note that there is a related literature exploring why democracies are less likely, as compared to other forms of government, to engage in conflict with any other governmental type. Discussions of the literature related to this claim can be found in Oneal and Ray (1997) and Oneal and Russet (1999).
} 
voting population, those that benefit from peace and economic openness, and opposition political parties (see Owen 1997; Russett 1993; Schultz 1998).

Several different sub-channels operate within the broader democratic politicalinstitutional environment that shape decisions on war versus peace between democracies (see Bueno de Mesquita and Lalman 1992; Russett 1993; Schultz 1998; Bueno de Mesquita et al. 1999; Bueno de Mesquita, Koch and Siverson 2004; Bueno de Mesquita 2006). One subchannel flows though the idea discussed above that democratic leaders are constrained by the preferences of the voting public. When this logic is expanded to international relations between democracies, it implies that both sides face constraints which make conflict less likely because of the aforementioned interests of groups having stakes in maintaining peace. A related subchannel is that public officials undertake conflicts only when they think they can win since losing will harm their chances for reelection. ${ }^{49}$ If two democracies know this, they will tend to have an incentive to reach some kind of peaceful settlement. Since democratic leaders will engage in war only when the relevant constituent groups are supportive, a commitment to war serves as credible signal that they are serious about conflict. This credible commitment to conflict again raises the benefit of reaching some kind of settlement. Finally, a third sub-channel is that the democratic process slows the mobilization of resources, thereby making war less likely. The underlying logic is that leaders must satisfy a variety of constituents and follow established procedural rules in order to engage in war. This limits the possibility of immediate

\footnotetext{
${ }^{49}$ However, an alternative viewpoint is that public officials may enter into conflict as a means of diverting the public's attention away from particular domestic issues. Diversionary war theory holds that when political leaders face opposition at home (e.g., because of economic downturns, unemployment, or political/military crises), they may resort to violence as a means of avoiding responsibility for those events. Hess and Orphanides (2001) argue that incumbent leaders may start prospectively avoidable conflicts in order to divert the electorate's attention away from a poorly performing economy. Such violence can be interstate or intrastate in nature, although the evidence is sparse for the former type of conflict. Tir and Jasinski (2008) is one example of empirical support for the diversionary use of force against ethnic minorities.
} 
resource mobilization, slowing the war process and making conflict less likely. Proponents of the democratic peace theory note that these mechanisms are either absent or weak in nondemocracies, which may provide insight into why non-democracies are more likely to engage in conflict with other states.

\subsubsection{Evidence for and against the democratic peace theory}

The earliest empirical test of the democratic peace hypothesis was carried out by Babst (1964, 1972), who reported support for the theory. Small and Singer (1976), however, responded to Babst, concluding that the evidence pointed in the opposite direction. This exchange can be seen as the origin of an academic controversy that continues to this day. ${ }^{50}$

Since the 1980s, a large number of empirical studies have built on this early literature. The most common design of these studies employ a dyadic approach that focuses on pairs of nations - e.g., the United States and France, or Germany and China. ${ }^{51}$ The empirical results are rather inconclusive. Many studies find support for the democratic peace hypothesis, even when militarized inter-state disputes are small scale in nature (Rummel, 1979; 1983; 1985; Maoz and Abdolali, 1989; Bremer, 1992; Maoz and Russett, 1992, 1993; Gleditsch, 1995; Russett, 1995; Rousseau et al., 1996; Raknerud and Hegre, 1997; Oneal and Russett, 1997, 1999; Beck, Katz, and Tucker, 1998; Bennet and Stam, 2000; Danilovic and Clare, 2007).

\footnotetext{
${ }^{50}$ Rummel $(1979,1983,1985)$ is another earlier contributor to the democratic peace debate. His empirical results support the theory's central prediction.

${ }^{51}$ For a discussion of some of the problems with this standard approach, see Ward, Siverson, and Cao (2007); and Maoz (2009). There is also a smaller literature which argues that democracies are more peaceful in generalwhether they interact with other democracies or non-democracies (see Benoit 1996; Boehmer 2008; Rummel 1995; Souva and Prins 2006). In general, the evidence for this position is weaker than that relating to dyadic peace between democracies.
} 
Mousseau (2000, 2003) confirms these empirical results after employing a set of different control variables, to capture the culture of contracting that arises in markets. Specifically, he argues that economic development fosters values and preferences which support democratic peace and democratic consolidation. These studies are especially interesting because they highlight how the origins of democratic norms and values are grounded in the market norms of contract - trust, interaction for mutual gain, equality before the law, etc. As the intensity of contracting increases in a society through increases in the extent of the market, so too do the associated values and norms. Mousseau's finding that contract intensity may be the actual cause of democracy and peace, calls into question the primacy of democracy in promoting peace. As we will discuss in further detail in the following section, these findings imply that democracy, by itself, may not be enough to ensure sustainable peace.

Building on this work, a more recent strand of literature focuses on how the level of economic development and the maturity of democratic institutions influence the likelihood of war between nations. Mousseau, Hegre and Oneal (2003) find that, if at least one of the two democratic countries involved in war has a low level of development, democracy per se does not prevent conflict. Specifically, Mousseau (2005) reports that democracy is a statistically significant determinant of peace only when both nations in a dyad have reached a level of development that exceeds the global median. He also finds that it is the poorest democracies that are likely to engage in conflict with other democracies. Similarly, Mansfield and Snyder (2005) accept the democratic peace thesis for mature or consolidated democracies, but reject it for immature democracies. Their argument is that immature democracies do not have welldeveloped checks and balances that constrain elected officials. In the absence of effective constraints, elected officials can use conflict as a means of rallying popular support. 
Mandelbaum (2007) emphasizes that liberty manifested in a limited and constrained government, in contrast to mob rule, is central to international peace. His logic is that popularly elected government officials absent effective checks on their behaviors can lead to perverse outcomes including conflict.

The empirical evidence supporting the democratic peace hypothesis has been supplemented by a variety of case studies that offer detailed analyses of examples which appear to violate the central claims of the democratic peace hypothesis (see Russett 1993; Ray 1993; Weart 1998). These authors conclude that events seemingly at odds with the democratic peace hypothesis are not so on closer inspection. The central issue is how democracy is defined with the implication being that a narrower definition of what constitutes a democracy will make it less likely that democracies have actually gone to war. For example, Ray (1993) notes that the following wars may be counted as wars between democracies under a broader definition of democracy: the American Revolution, the French Revolutionary Wars, the War of 1812, the Belgian Revolution, the American Civil War, the Spanish American War, World War I, World War II, the Israeli War of Independence, and the Yugoslav Wars.

On the other hand, some participants in the debate on the explanatory power of the theory of the democratic peace charge that its supporters define democracy narrowly, thereby excluding examples that cut against the theory's predictions (see, for example, Layne 2001). Doyle (1983a,b), Ray (1993), and Russett (1993), for instance, all qualify their definitions of democracy so as to exclude the War of 1812, the Spanish-American War and World War I, all of which seem to contradict the democratic peace hypothesis (see Rosato 2011). The tendency to restrict the sample of democracies by adopting restrictive definitions of governmental types, the 
critics contend, limits the explanatory power of studies supporting the democratic peace hypothesis.

Others have called into question the robustness of previous findings supporting the theory. For example, Oneal et al. (1996) re-estimate the model of Maoz and Russett (1993) and find that it is not robust to the inclusion of a variable that captures economic interdependence between countries derived from bilateral trade flows. Oneal and Ray (1997) propose an alternative measure of democracy, which relies on the democratic score, from the Polity III index, of the less democratic state in each dyad. Using this new measure, they put forth support for the democratic peace hypothesis. Specifically, their results suggest that as the less democratic state in each dyad becomes more democratic, the likelihood of interstate conflict falls.

Rosato (2003) scrutinizes the fundamental claim that democracy causes peace, given the main consensus in the literature that joint democracy-i.e. two countries in a dyad are both democratic - is associated with peace. He contends that if democracy is actually the cause of peace then a monadic effect should exist. He tests the democratic peace theory along these lines and does not find support for the central claims of the theory. ${ }^{52}$ This is likely consistent with a series of studies contending that it is the similarity between the form of political institutions of states, and not democracy per se, that is a main driver of peace. For example, Raknerud and Hegre (1997) find that there is actually an "autocratic peace effect," whereby two nondemocratic states are less likely to engage in war. Werner (2000) further buttresses the 'political similarity' hypothesis, noting that the 'democratic peace' is the result of comparing a restricted subset of similarly governed states.

\footnotetext{
${ }^{52}$ See Rosato (2005) for a response to some of the criticisms of this approach.
} 
In addition to the literature on political similarity, a series of studies consider alternative, non-democratic explanations for peace. The authors of these studies hold that joint democracy is one of only several potential explanations for peace and that the findings of previous studies supporting that hypothesis may be spurious. Farber and Gowa (1995) and Henderson (2002) emphasize the importance of alliances formed during the Cold War as contributor to peace. Rauchhaus (2009) suggests that when there is a nuclear symmetry across states (i.e., two countries both have nuclear arsenals), peaceful stability emerges. However, when there is asymmetry across states (i.e., one state has a nuclear weapon but another does not), then the likelihood of an interstate dispute rises. Another line of research, which we will discuss in more detail in the next section, emphasizes the relative importance of economic factors. Other scholars, such as Gibler (2007), highlight the role of stable borders. After controlling for the absence of territorial disputes, he finds that the absence of democracy is irrelevant in explaining the onset of conflict.

Yet another line of criticism has been leveled at the two main theoretical channelsnorms and political institutions - through which the democratic peace supposedly operates. For example, Reiter and Stam (2002) point to cases where democratic states have used military force to advance their narrow interests as instances that stand in contrast to the liberal democratic norms associated with respect, tolerance and peace. In terms of political institutions, Chiozza and Goemans (2004) find that losing a war significantly reduces the tenure of autocrats, but does not materially impact the tenure of democratically elected leaders. Weeks (2008) concludes that non-democratic leaders are as accountable for war as their democratic counterparts, which runs counter to the claim that democratic political institutions impose a unique set of checks and balances that limit the likelihood of conflict between states. 
Critics also have also raised questions regarding the effectiveness of specific groups and constituents in limiting the initiation of violent conflict. The issue is that just as there can be groups opposed to conflict, groups favoring it can also influence policy. For example, Snyder (1991) discusses how logrolling among pro-war coalitions contributed to U.S. involvement in the Korean and Vietnam Wars. Studies by Desch (2002) and Downes (2009) report that democracies are no more likely to wage war than non-democracies. These empirical results cut against the prediction that democracies will enter wars only when they expect to win and that this serves as a signal of credible commitment which contributes to the peaceful resolution of disputes.

In sum, the democratic peace hypothesis is one of the most widely accepted claims regarding international relations among politicians, practitioners, and academics. Despite this widespread acceptance, there is ongoing debate regarding the accuracy of the theory's central claims.

\subsection{The capitalist peace theory}

\subsubsection{Background and theory}

In contrast to the democratic peace theory, the capitalist peace theory holds that economic ties between countries are the primary cause of peaceable international relations. The notion of the capitalist peace has a long history that can be traced back to Montesquieu, Adam Smith, Thomas Paine, Frederic Bastiat, John Stuart Mill, and Richard Cobden (Gratzke 2007). At its core, the capitalist peace theory predicts that inter-state trade and other economic connections between nations raise the cost of interstate conflict as the result of the benefits flowing from repeated 
interactions. Close economic ties reduce uncertainty about future relations, providing an incentive to resolve potential conflicts without resorting to violence.

Gartzke (2007, p. 171) identifies three channels through which capitalism can contribute to peace. First, countries with similar policy goals have little to gain by forcibly trying to change the policies of their trading partners. Second, the dynamism of capitalist economies allows both parties to benefit, through trade, from differences in resource endowments and comparative advantages. Third, if the relevant parties can foresee the potential future gains from peace, or potential future losses from conflict, they will have stronger incentives to work toward negotiating peaceful resolutions to any disagreement. Dorussen and Ward (2010) highlight how economic traders become mediators in potential conflict situations because they have such large stakes in the continuation of peace. As with the democratic peace theory, the central claim of the capitalist peace theory is not that capitalism will eradicate conflict completely, but rather that conflict is less likely between countries that are integrated economically.

While some scholars see democratic peace and capitalist peace as competing explanations for the avoidance of conflict, the two are more accurately viewed as being related. Scholars such as F.A. Hayek (1944) and Milton Friedman (1962) argue that economic freedom is a precondition for political freedom. More recently, Lawson and Clark (2010) have tested the Friedman-Hayek hypothesis and find that it holds up reasonably well. Likewise, Mousseau $(2000,2002,2003,2005,2009)$ argues that democracy is a descendent of contract-intensive economies, further highlighting the connection between economic freedom and democracy. Scholars such as Hegre $(2003)$ and Weede $(2004,2006)$ have underscored the importance of economic development, which results from economic freedom, to the emergence of effective 
democratic institutions. ${ }^{53}$ Weede (2011) views democracy as one channel through which capitalism can promote peace. Given this interconnection between political and economic institutions, a central question in the literature is whether trade and economic interconnectedness is more or less important than democracy for peace.

\subsubsection{Evidence for and against the capitalist peace theory}

Numerous empirical studies support the claim of an inverse relationship between dyadic trade and conflict (see Gartzke and Li 2003; Oneal 2003; Oneal, Russett and Berbaum 2004; Dorussen 2006; Xiang, Xu and Keteku 2007). ${ }^{54}$ The empirical approach of Souva and Prins (2006) posits that in addition to trade, foreign investment also has a positive effect on peace. Gartzke (2005, 2007, 2009) puts forth evidence that economic freedom and financial market openness reduce the likelihood of war. Furthermore, after controlling for financial market openness, Gartzke (2007, 2008) illustrates that democracy has little or no independent effect on peace. McDonald (2009) employs alternative measures of economic freedom and concludes that free markets have a stronger effect on peace than political freedom does.

Boemher and Nordstrom (2008) conclude that strong trade relations between states are the most important determinant of joint participation in international organizations (see also Dourussen and Ward 2008, 2010). The underlying idea is that membership in multilateral organizations further strengthens economic ties and thus contributes to the capitalist peace.

While empirical evidence supporting the capitalist peace theory exists, there hasn't been a firm consensus in the literature to date. Barbieri (2002) provides an empirical analysis of the

\footnotetext{
${ }^{53}$ It should be noted that an ongoing debate questions the relationship between democracy and economic growth (see Knack and Keefer 1995; Dede Haan 1996; Hall and Jones 1999; Barro 1997; Tavares and Wacziarg 2001).

${ }^{54}$ See Barbieri, Keshk and Pollins (2009) for a discussion of the limits of existing trade data.
} 
relationship between trade and conflict from 1870 to 1992 . He fails to find support for the capitalist peace theory. Goenner (2004) remarks that empirical studies on this relationship easily can suffer from omitted variable bias. Applying Bayesian averaging, he tests several alternatives and finds that trade interdependence does not explain peace, but that joint democracy does. Likewise, Kim and Rousseau (2005) question previous results regarding the primacy of trade over democracy for peace. Using data from international disputes during 1960-1988, they find no statistical evidence of the pacifying effect of trade. Like Goenner (2004), they argue that earlier models were misspecified, resulting in spurious results.

Another question motivating recent research on the capitalist peace theory is whether, and how, the composition of trade matters. The motivating question underlying this strand of research is whether the negative relationship between trade and conflict holds across all goods or only for certain tradables. In its strong form, the capitalist peace thesis holds that trade promotes peace in general. However, a weaker form of the thesis may be valid in which trade in "strategic goods" may reduce the peace-related benefits of international exchange and, hence, actually increase the potential for conflict.

One of the earliest studies to bring attention to the issue of the heterogeneity of trade was Hirchmann's (1945) analysis of how the German National Socialists used trade to strengthen their domestic political power. Specifically, he highlights how German policy focused on exporting finished manufactured goods to Eastern Europe to make these countries more dependent on German industry. According to Hirchmann (1945), the creation of this trade dependence allowed the Nazis to pursue their foreign policy objectives aggressively.

Likewise, some researchers emphasize that that when war increases the relative price of exports, exporting countries may become more hostile toward importing countries. Polachek 
(1980) identifies this mechanism at work in the case of oil exporters and oil importers. Li and Rueveny (forthcoming) build on Polachek and specify the conditions under which one member of a dyad is likely to engage in conflict against its pair. The likelihood of conflict depends on the number of alternative buyers and sellers, as well as on the sensitivity of each party's supply and demand to conflict. Dorussen and Ward (2011) raise some issues with the models of Polachek and Li and Rueveny. They point out that these models neglect the possibility of a third party intervening to avoid conflict. This is not an unreasonable possibility given the widespread benefits of trade that extend beyond dyads. Further, Dorussen and Ward point out that even if conflict can generate better terms of trade for one country, it is unclear that this necessarily would lead to war. It is possible that greater hostility by one country would not be met with greater hostility by the other.

In general, a central issue with empirical studies attempting to address the importance of strategic goods is defining what goods comprise that category. One approach has been to identify tradable goods that are more likely to lead to war. For example, Dorussen (2006) contends that goods whose production is concentrated in few hands-e.g., energy, minerals and mining - are more likely to lead to conflict than are production processes rely heavily on foreign capital. Goenner (forthcoming) employs the Herfindahl-Hirschman Index, a measure of industrial concentration, as a means of identifying "strategic goods." In doing so, he categorizes the production of energy, non-ferrous metals and nuclear materials as tradables that plausibly increase the likelihood of war.

Large-N statistical analyses of heterogeneous trade are relatively new and only a handful of studies exist to date. Gasiorowski and Polachek (1982) analyze U.S.-Warsaw Pact trade and conflict data during détente (the easing of U.S.-Soviet hostilities). Increases in East-West trade, 
they conclude, led to a significant decline in U.S.-Warsaw Pact conflict. Disaggregating trade, they find trade in manufactured goods to be especially pacifying. Polachek and McDonald (1992) support this hypothesis in empirical specifications using manufactured goods. Dorussen (2006) argues that the relationship is stronger for manufactured goods, except for chemical and metal industries, and weaker for commodities that are easier to take by force. Li and Rueveny (forthcoming) also surmise that trade in energy contributes to the increased likelihood of conflict. $^{55}$

As noted earlier, scholarly research has focused recently on the relationships between trade, intergovernmental organizations and peace. To reiterate, the underlying logic is that in addition to the direct benefits of dyadic trade, there are also spillover benefits for other countries. The flow of trade between two countries influences indirectly the flow of trade between other trading partners that are outside that dyad. Dorussen and Ward $(2008,2010,2011)$ have incorporated both network effects and heterogeneous trade into their empirical studies and find that conflict is less likely when countries are part of the global network of trade. Interestingly, they also find that heterogeneity in the goods traded does not matter as much after controlling for membership in trade networks.

In sum, there is some, but by no means complete, consensus of an inverse relationship between international trade and international conflict. Proponents of the capitalist peace theory agree that the composition of trade also matters. However, there is disagreement regarding exactly what goods contribute either to peace or conflict. At least in the short-term the focus of

\footnotetext{
${ }^{55}$ Dorussen and Ward (2011) point to some of the limits of these studies, including differences in definitions of conflict, the level of aggregation in trade data, and model specification. Ideally, dyadic trade flows at the commodity level would be analyzed to identify the specific goods that contribute to peace or conflict (Polachek 1992, 1999). However, because of data limitations, each of the existing empirical studies approaches the problem idiosyncratically, making it difficult to compare the findings across studies (Dorussen and Ward 2011).
} 
research on the capitalist peace theory will most likely continue to revolve around issues of alternative model specifications and trade data aggregation. To some extent, these issues are driven by the absence of a solid theoretical understanding of how heterogeneous goods influence peace and conflict (see Dorussen and Ward 2011). The other area of continuing research will be on understanding and quantifying not just the direct benefits of trade on peace, but also the indirect effects as well. Finally, regarding the connection between theories of democratic peace or capitalist peace, one remaining research question is whether political or economic factors dominate.

\section{Conclusion}

In this chapter, we have assessed the political economy of war and peace, highlighting how institutions influence conflict and contribute to the emergence and consolidation of intrastate and interstate peace.

For future research on the role of institutions for conflict, scholars can benefit from the gathering of new information on these topics. Regan, Frank, and Clark (2009), for instance, have developed a detailed dataset on institutions and elections between 1972 and 2005, with descriptions of the different constraints imposed by political and legal institutions as well as how disparate agents are incorporated into polities across countries.

Given the interplay of institutions and political leaders (see Jones and Olken, 2009, for instance), scholars can also take advantage of the data on political leaders contained in Goemans, Gleditsch, and Chiozza (2009). Institutional change is typically an internal phenomenon, thus understanding the incentives of the political elite within particular countries is crucial. After all, 
as Olson (2000, p. 3) noted, "historical outcomes surely depend not only on the incentives and self-interest of those with power but also on their morals and temperaments."

Along with empirical assessments of conflict, there needs to be a greater analytical understanding of how institutions influence conflict and cooperation directly and indirectly, by disaggregating them into specific constraints (and incentives). Historical, behavioral, and micro study-based analyses of conflict will also contribute to our understanding of the causes and consequences of inter-state and intra-state conflict. 


\section{References}

Acemoglu, D., S. Johnson, and J.A. Robinson (2001), 'The Colonial Origins of Comparative Development: An Empirical Investigation’, American Economic Review, 91 (5), 1369-1401.

Acemoglu, D. (2003), 'Why Not a Political Coase Theorem? Social Conflict, Commitment, and Politics', Journal of Comparative Economics, 31, 620-652.

Acemoglu, D. and S. Johnson (2005), 'Unbundling Institutions', Journal of Political Economy 113 (5), 949-994.

Acemoglu, D., J.A. Robinson, and R.J. Santos (2010), 'The Monopoly of Violence: Evidence from Colombia', Mimeo.

Azam, Jean-Paul and Alice Mesnard (2003), 'Civil War and the Social Contract.' Public Choice, 115, 455-475.

Azam, J.-P. (2006), 'The Paradox of Power Reconsidered: A Theory of Political Regimes in Africa', Journal of African Economies, 15, 26-58.

Babst, D.V. (1964), 'Elective Governments: A Force for Peace', The Wisconsin Sociologist, 2, 9-14. . (1972), 'A Force for Peace', Industrial Research, 14 (April), 55-58.

Barbieri, Katherine (2002), The Liberal Illusion. Does Trade Promote Peace? Ann Arbor, MI: The University of Michigan Press.

Barbieri, K., O. M. G. Keshk, and B. M. Pollins (2009), 'Trading Data: Evaluating our Assumptions and Coding Rules', Conflict Management and Peace Science, 26 (5), 471-491.

Barro, Robert, J. (1997), Determinants of Economic Growth: A Cross-Country Empirical Study, Massachusetts, MA: MIT Press.

Basuchoudhary, Atin and Shughart II, William F (2010), 'On Ethnic Conflict and the Origins of Transnational Terrorism', Defence and Peace Economics, 21 (1), 65-87.

Beck, N., J. N. Katz, and R. Tucker (1998), 'Taking Time Seriously', American Journal of Political Science, 42 (4), 1260-1288.

Bennett, A. and G. J. Ikenberry (2006), 'The Review's Evolving Relevance for U.S. Foreign Policy 1906-2006', American Political Science Review, 100 (4), 651-658. 
Bennett, D.S. and A.C. Stam (2000), 'Research Design and Estimator Choices in the Analysis of Interstate Dyads: When Decisions Matter', The Journal of Conflict Resolution, 44 (5), 653-685.

Benoit, K. (1996), 'Democracies Really Are More Pacific (in General)', Journal of Conflict Resolution, 40 (4), 636-657.

Bernholz, P. (2006), 'International Political System, Supreme Values, and Terrorism,' Public Choice, 128 (1-2), 221-231.

Besley, Timothy and Torsten Persson (2009), 'The Logic of Political Violence', Working paper. Available at http://econ.lse.ac.uk/staff/tbesley/papers/PoliticalVilolence.pdf.

Besley, Timothy and Torsten Persson (2009), 'The Origins of State Capacity: Property Rights, Taxation, and Politics', American Economic Review, 99 (4), 1218-1244.

Blattman, Christopher and E. Miguel (2010), 'Civil War', Journal of Economic Literature, 48 (1), 3-57.

Boehmer, C.R. (2008), 'A Reassessment of Democratic Pacifism at the Monadic Level of Analysis', Conflict Management and Peace Science, 25 (1), 81-94.

Boehmer, C.R. and T. Nordstrom (2008), 'Intergovernmental Organization Memberships. Examining Political Community and the Attributes of Political Organizations', International Interactions, 34 (3), 282-309.

Brabazon, J. (2003), 'Taylor's Nemesis', BBC Focus on Africa (October-December), 10-13.

Braithwaite, Alex (2010), 'Resisting Infection: How State Capacity Conditions Conflict Contagion', Journal of Peace Research, 47 (3), 311-319.

Bremer, S.A. (1992), 'Dangerous Dyads: Conditions Affecting the Likelihood of Interstate War 1816-1965', Journal of Conflict Resolution, 36 (2), 309-341.

Bueno de Mesquita, B. (2006), 'Game Theory, Political Economy, and the Evolving Study of War and Peace', American Political Science Review, 100 (4), 637-642.

Bueno de Mesquita, Bruce and David Lalman (1992), War and Reason: Domestic and International Imperatives, New Haven, CT: Yale University Press.

Bueno de Mesquita, B., M.T. Koch, and R.M. Siverson (2004), 'Testing Competing Institutional Explanations of the Democratic Peace: The Case of Dispute Duration', Conflict Management and Peace Science, 21 (4), 255-267.

Bueno de Mesquita, B., J.D. Morrow, R.M. Siverson, and A. Smith (1999), 'An Institutional Explanation of the Democratic Peace', American Political Science Review, 93 (4), 791-807. 
Buchanan, James. M. (1975), The Limits of Liberty: Between Anarchy and Leviathan. Chicago, IL: Chicago University Press.

Cederman, L. and L. Girardin (2007), 'Beyond Fractionalization: Mapping Ethnicity onto Nationalist Insurgencies', American Political Science Review, 101 (1), 173-185.

Cederman, L, S. Hug, and L. Krebs (2010), 'Democratization and Civil War: Empirical Evidence', Journal of Peace Research, 47 (4), 377-394.

Chiozza, G. and H.E. Goemans (2004), 'International Conflict and the Tenure of Leaders: Is War Still Ex Post Inefficient?', American Journal of Political Science, 48 (3), 604-619.

Choi, Seung-Whan (2010), 'Legislative Constraints: A Path to Peace?' Journal of Conflict Resolution, 54 (3), 438-470.

Coll, Steve (2004), Ghost Wars: The Secret History of the CIA, Afghanistan, and bin Laden, from the Soviet Invasion to September 10, 2001. New York: Penguin.

Collier, P. and A. Hoeffler (1998), 'On the Economic Causes of Civil War', Oxford Economic Papers, 50 (4), 563-573.

. (2004), 'Greed and Grievance in Civil War.' Oxford Economic Papers, 56 (4), 563-595.

. (2007), 'Civil War', In Sandler, Todd and K. Hartley (eds.), Handbook of Defense

Economics, Vol 2: Defense in a Globalized World. Amsterdam and Oxford, North-Holland (Elsevier).

Collier, P., V.L. Elliott, H. Hegre, A. Hoeffler, M. Reynal-Querol, and N. Sambanis (2003), Breaking the Conflict Trap: Civil War and Development Policy, World Bank Policy Research Report.

Cowen, T. (2004), 'A Road Map to Middle Eastern Peace? A Public Choice Perspective', Public Choice, 118 (1-2), 1-10.

Coyne, C.J. (2008), After War: The Political Economy of Exporting Democracy, California: Stanford University Press.

Cramer, C. (2002), 'Homo Economicus Goes to War: Methodological Individualism, Rational Choice and the Political Economy of War', World Development, 30 (11), 1845-64.

Cunningham, D.E. (2006), 'Veto Players and Civil War Duration', American Journal of Political Science, 50 (4), 875-892.

Danilovic, V. and J. Clare (2007), 'The Kantian Liberal Peace', American Journal of Political Science, 51 (2), 397-414. 
De Haan, J. (1996), 'New Evidence on the relationship Between Democracy and Economic Growth', Public Choice, 86 (1), 175-198.

De Soysa, I. and H. Fjelde (2010), 'Is the Hidden Hand an Iron Fist? Capitalism and Civil Peace, 1970-2005', Journal of Peace Research, 47 (3), 287-298.

Derouen, Karl R. Jr. and J. Bercovitch (2008), 'Enduring Internal Rivalries: A New Framework for the Study of Civil War', Journal of Peace Research, 45 (1), 55-74.

Desch, M.C. (2002), 'Democracy and Victory: Why Regime Type Hardly Matters', International Security, 27 (2), 5-47.

Dixon, W.J. (1994), 'Democracy and the Peaceful Settlement of International Conflict', American Political Science Review, 88 (1), 14-32.

Downes, A.B. (2009), 'How Smart and Tough Are Democracies? Reassessing Theories of Democratic Victory in War', International Security, 33 (4), 9-51.

Doyle, M.W. (1983a), 'Kant, Liberal Legacies, and Foreign Affairs, Part 1', Philosophy and Public Affairs, 12 (3), 205-235.

(1983b), 'Kant, Liberal Legacies, and Foreign Affairs, Part 2', Philosophy and Public Affairs 12 (4), 323-353.

Dorussen, H. (2006), 'Heterogeneous Trade Interests and Conflict', Journal of Conflict Resolution, 50 (1), 87-107.

Dorussen, H. and H. Ward (2008), 'International Organizations and the Kantian Peace. A Network Perspective', Journal of Conflict Resolution, 52 (2), 189-212.

42.

(2010), 'Trade Networks and the Kantian Peace', Journal of Peace Research, 47 (1), 29-

(2011), 'Disaggregated Trade Flows and International Conflict', in Christopher J. Coyne and Rachel L. Mathers (eds.), The Handbook on the Political Economy of War, Cheltenham, UK: Edward Elgar Publishing, Inc., in press.

Easterly, W. (2001), 'Can Institutions Resolve Ethnic Conflict?,' Economic Development and Cultural Change, 49 (4), 687-706.

Edwards, R.D. (2010), 'A Review of War Costs in Iraq and Afghanistan', NBER Working Paper, No. 16163. 
Elbadawi, I., and N. Sambanis (2000), 'Why Are There So Many Civil Wars in Africa? Understanding and Preventing Violent Conflict', Journal of African Economics, 9 (3), 244-269.

. (2002), 'How Much War Will We See? Explaining the Prevalence of Civil War', Journal of Conflict Resolution, 46 (3), 307-34.

Evensky, J. (2005), 'Adam Smith's Theory of Moral Sentiments: On Morals and Why They Matter to a Liberal Society of Free People and Free Markets', Journal of Economic Perspectives, 19 (3): 109-130.

Farber, H.S. and J. Gowa (1995), 'Polities and Peace', International Security, 20 (2), 123-146.

Fearon, J. D. (1995), 'Rationalist Explanations for War', International Organization, 49 (3), $379-414$.

. (2004), 'Why Do Some Civil Wars Last So Much Longer than Others?', Journal of Peace Research, 41 (3), 275-301.

. (2007), 'Economic Development, Insurgency, and Civil War', in Elhanan Helpman (ed.), Institutions and Economic Performance, Cambridge, MA: Harvard University Press, pp. 292328.

Fearon, James D. and D.D. Laitin (1996), 'Explaining Interethnic Cooperation', American Political Science Review, 90 (4), 715-735.

Fearon, James D. and D.D. Laitin (2003), 'Ethnicity, Insurgency, and Civil War', American Political Science Review, 97 (1), 75-90.

Fielding, D. and A. Shortland (2010), 'An Eye for an Eye, a Tooth for a Tooth': Political Violence and Counter-Insurgency in Egypt', Journal of Peace Research, 47 (4), 433-448.

Flores, T.E. and I. Nooruddin (2009), 'Democracy Under the Gun: Understanding Postconflict Economic Recovery', Journal of Conflict Resolution, 53 (1), 3-29.

Friedman, Milton (1962), Capitalism and Freedom, Chicago, IL: University of Chicago Press.

Garfinkel, Michelle and Stergios Skaperdas (1996), The Political Economy of Conflict and Appropriation, Cambridge, UK: Cambridge University Press.

Garfinkel, M. R. (1990), 'Arming as a Strategic Investment in a Cooperative Equilibrium', American Economic Review, 80 (1), 50-68.

Garfinkel, Michelle R., and S. Skaperdas (2000), 'Conflict without Misperceptions or Incomplete Information: How the Future Matters', Journal of Conflict Resolution, 44 (6), 793-807.

Gartzke, E. (1999), 'War is in the Error Term', International Organization, 53 (3), 567-587. 
. (2005), 'Freedom and Peace', in James D. Gwartney and Robert A. Lawson (eds.), Economic Freedom in the World, Vancouver, BC: Fraser Institute, pp. 29-44.

. (2007), 'The Capitalist Peace', American Journal of Political Science, 51 (1), 166-191.

. (2009), 'Production, prosperity, preferences, and peace', in Peter Graeff and Guideo

Mehlkhop (eds.), Capitalism, Democracy, and the Prevention of War and Poverty. London:

Routledge, pp. 31-60.

Gartzke, E. and Q. Li (2003), 'Measure for Measure: Concept Operationalization and the Trade Interdependence - Conflict Debate', Journal of Peace Research, 40 (3), 553-571.

Gasiorowski, M. and S.W. Polachek (1982), 'East-West Trade and Linkages in the Era of Détente', Journal of Conflict Resolution, 26 (4), 709-729.

Gates, S. (2002), 'Recruitment and Allegiance: The Microfoundations of Rebellion', Journal of Conflict Resolution, 46 (1), 111-130.

Gelpi, C.F. and M. Griesdorf (2001), 'Winners or Losers? Democracies in International Crisis, 1918-94', American Political Science Review, 95 (3), 633-647.

Ghobarah, H.A., P. Huth, and B. Russett (2003), 'Civil Wars Kill and Maim People—Long After the Shooting Stops', American Political Science Review, 97 (2), 189-202.

Gibler, D.M. (2007), 'Bordering on Peace: Democracy, Territorial Issues, and Conflict', International Studies Quarterly, 51 (3), 509-532.

Glaeser, Edward L. (2005) 'The Political Economy of Hatred', The Quarterly Journal Economics, 120 (1), 45-86.

Gleditsch, N.P. (1995), 'Geography, Democracy, and Peace', International Interactions, 20 (4), 297-323.

Gleditsch, Nils Petter, P. Wallensteen, M. Eriksson, M. Sollenberg, and H. Strand (2002), 'Armed Conflict 1946-2001: A New Dataset', Journal of Peace Research, 39 (5), 615-637.

Gleditsch, K.S. and A. Ruggeri (2010), 'Political Opportunity Structures, Democracy, and Civil War', Journal of Peace Research, 47 (3), 299-310.

Glick, R. and A.M. Taylor (2010), 'Collateral Damage: Trade Disruption and the Economic Impact of War', Review of Economics and Statistics, 92 (1), 102-27.

Goemans, H.E., K.S. Gleditsch, and G. Chiozza (2009), 'Introducing Archigos: A Dataset of Political Leaders', Journal of Peace Research, 46 (2), 269-83. 
Goenner, C. F. (2004), 'Uncertainty of the Liberal Peace', Journal of Peace Research, 41 (5), 589-605.

- (Forthcoming), 'From Toys to Warships: Interdependence and the Effects of Disaggregated Trade on Militarized Disputes', Journal of Peace Research.

Grossman, H. I. (1991), 'A general equilibrium model of insurrections', The American Economic Review, 81 (4), 912-921.

Grossman, Herschel I. and Minseong Kim (1996), 'Predation and Production', in Michelle R. Garfinkel and Stergios Skaperdas (eds.), The Political Economy of Conflict and Appropriation, Cambridge, UK, Cambridge University Press, pp. 57-72.

Gould, J.P. (1973), 'The Economics of Legal Conflicts', The Journal of Legal Studies, 2 (2), 279-300.

Guidolin, Massimo and E. La Ferrara (2007), 'Diamonds Are Forever, Wars Are Not: Is Conflict Bad for Private Firms?’ American Economic Review, 97 (5), 1978-1993.

Halperin, E. (2008), 'Group-based Hatred in Intractable Conflict', Journal of Conflict Resolution, 52 (5), 713-736.

Hall, R. E. and C.I. Jones (1999), 'Why Do Some Countries Produce so Much More Output per Worker than Others?', Quarterly Journal of Economics, 114 (1), 83-116.

Harbom, L. and P. Wallensteen (2010), 'Armed Conflicts, 1946-2009', Journal of Peace Research, 47 (4), 501-509.

Hayek, F.A. [1944] (1976), The Road to Serfdom, Chicago, IL: University of Chicago Press.

Hegre, H. (2003), 'Disentangling Democracy and Development as Determinants of Armed Conflict', The World Bank, Mimeo.

Hegre, H., T. Ellingsen, S. Gates, and N.P. Gleditsch (2001), 'Toward a Democratic Civil Peace? Democracy, Political Change, and Civil War, 1816-1992', American Political Science Review, $95(1), 33-48$.

Hegre, H., G. Ostby, and C. Raleigh (2009), 'Poverty and Civil War Events: A Disaggregated Study of Liberia', Journal of Conflict Resolution, 53 (4), 598-623.

Hendrix, Cullen S. (2010), 'Measuring State Capacity: Theoretical and Empirical Implications for the Study of Civil Conflict', Journal of Peace Resarch, 47 (3), 273-285. 
Hess, G., and A. Orphanides (2001), 'War and democracy', Journal of Political Economy, 109 (4), 776-810.

Hirschleifer, J. (1989), 'Conflict and Rent-Seeking Success Functions: Ratio vs. Difference Models of Relative Success', Public Choice, 63 (2), 101-112.

. (1991), 'The technology of conflict as an economic activity', The American Economic Review, 81 (2), 130-134.

. (1996), 'Anarchy and Its Breakdown', in Michelle R. Garfinkel and Stergios Skaperdas (eds.), The Political Economy of Conflict and Appropriation, Cambridge, UK, Cambridge University Press, pp. 15-40.

Hirschmann, Albert O. (1945), National Power and the Structure of Foreign Trade, Berkeley, CA, US: University of California Press.

Holcombe, Randall G. (1994), The Economic Foundations of Government, New York: New York University Press. 11-19. (2008), 'Why Does Government Produce National Defense?', Public Choice, 137 (1-2),

Horowitz, Donald L. (1985), Ethnic Groups in Conflict, Berkeley, CA: University of California Press.

Huntington, Samuel P. (1968), Political Order in Changing Societies. New Haven, CT: Yale University Press.

Huntington, Samuel P. (1996), The Clash of Civilizations and the Remaking of World Order, New York, NY: Simon and Schuster.

Jackson, P. (2002), 'March of the Lord's Resistance Army: Greed or Grievance in Northern Uganda?', Small Wars and Insurgencies, 13 (3), 29-52.

Jacobsson, A.K.S. (2009), 'War and Peace-Cyclical Phenomena?', Public Choice, 141 (3-4), 467-480.

Jaeger, D.A. and M.D. Paserman (2008), 'The Cycle of Violence? An Empirical Analysis of Fatalities in the Palestinian-Israeli Conflict', American Economic Review, 98 (4), 1591-1604.

Jefferson, Thomas. [1785] (2009), 'Letter to Edmund Randolph', in Brett F. Woods (ed.), Thoughts on War and Revolution, New York, NY: Algora Publishing, pp. 37-38.

Jones, B.F. and B.A. Olken (2009), 'Hit or Miss? The Effect of Assassinations on Institutions and War', American Economic Journal: Macroeconomics, 1 (2), 55-87. 
Kalyvas, Stathis (2007), 'Civil Wars', in Carles Boix and Susan C. Stokes (eds.), The Oxford Handbook of Comparative Politics, New York: Oxford University Press, pp. 416-434.

Kant, Immanuel [1795] (1983), Perpetual Peace and Other Essays, Indianapolis, IN: Hackett Publishing Company, Inc.

Keefer, P. (2008), 'Insurgency and Credible Commitment in Autocracies and Democracies', World Bank Economic Review, 22 (1), 33-61.

Kim, H. M. and D.L. Rousseau (2005), 'The Classical Liberals Were Half Right (or Half Wrong): New Tests of the 'Liberal Peace', 1960-88', Journal of Peace Research, 42 (5), 523543.

Kimenyi, M.S. and R.G. Romero (2008), 'Identity, Grievances, and Economic Determinants of Voting in the 2007 Kenyan Elections', University of Connecticut Department of Economics Working Paper Series, WP 2008-38.

Kirk, Richard M. (1983), 'Political Terrorism and the Size of Government: A Positive Institutional Analysis of Violent Political Activity’, Public Choice, 40 (1), 41-52.

Kydland, F.E. and E.C. Prescott (1977), 'Rules Rather than Discretion: The Inconsistency of Optimal Plans', Journal of Political Economy, 85 (3), 473-492.

Knack, S. and P. Keefer (1995), 'Institutions and Economic Performance: Cross-Country Tests Using Alternative Measures', Economics and Politics, 7 (3), 207-227.

Krueger, A. (1974), 'The Political Economy of the Rent-Seeking Society', American Economic Review, 64 (3), 291-303.

Layne, C. (2001), 'Shell Games, Shallow Gains, and the Democratic Peace', International History Review, 23 (4), 799-813.

Lawson, R.A. and J.R. Clark (2010), 'Examining the Hayek-Friedman Hypothesis on Economic and Political Freedom', Journal of Economic Behavior and Organization, 74 (3), 230-239.

Leeson, P. (2005), 'Endogenizing Fractionalization', Journal of Institutional Economics, 1 (1), 75-98.

Leventoğlu, Bahar and B.L. Slantchev (2007), 'The Armed Peace: A Punctuated Equilibrium Theory of War', American Journal of Political Science, 51 (4), 755-771. 
Levy, Jack S. (1989), 'The Causes of War: A Review of Theories and Evidence', in Philip E. Tetlock, Jo L. Husbands, Robert Jervis, Paul C. Stern, and Charles Tilly (eds.), Behaviour, Society and Nuclear War, Volume 1, New York, NY: Oxford University Press, pp. 209-333.

Landes, W.M. (1971), 'An Economic Analysis of the Courts,' Journal of Law and Economics, 14 (1), 61-107.

Li, Q. and R. Reuveny (Forthcoming), 'Trading for Peace? Disaggregated Bilateral Trade and Interstate Military Conflict Initiation', Journal of Peace Research.

Lipson, Charles. (2003), Reliable Partners: How Democracies Have Made a Separate Peace, Princeton, N.J.: Princeton University Press.

Mandelbaum, Michael (2007), Democracy's Good Name. The Rise and Risks of the World's Most Popular Form of Government, New York, NY: Public Affairs Press.

Mansfield, Edward D. and Jack Snyder (2005), Electing to Fight. Why Emerging Democracies Go to War, Cambridge, MA: MIT Press.

Maoz, Z. (2009), 'The Effects of Strategic and Economic Interdependence on International Conflict Across Levels of Analysis', American Journal of Political Science, 53 (1), 223-240.

Maoz, Z. and N. Abdolali (1989), 'Regime Types and International Conflict, 1816-1976', Journal of Conflict Resolution, 33 (1), 3-35.

Maoz, Z. and B. Russett (1992), 'Alliance, Contiguity, Wealth, and Political Stability: Is the Lack of Conflict Among Democracies a Statistical Artifact?', International Interactions, 17 (3), 245-267.

(1993), 'Normative and Structural Causes of Democratic Peace, 1946-1986', American Political Science Review, 87 (3), 624-638.

McDonald, Patrick (2009), The Invisible Hand of Peace, Cambridge, UK: Cambridge University Press.

Miguel, E., S. Satyanath, and E. Sergenti (2004), 'Economic Shocks and Civil Conflict: An Instrumental Variables Approach', Journal of Political Economy, 112 (4), 725-753.

Mizuno, N. and R. Okazawa (2009), 'Colonial Experience and Postcolonial Underdevelopment in Africa’, Public Choice, 141 (3-4), 405-419.

Mousseau, M. (2000), 'Market Prosperity, Democratic Consolidation, and Democratic Peace', Journal of Conflict Resolution, 44 (4), 472-507. 
. (2002), 'An Economic Limitation to the Zone of Democratic Peace and Cooperation', International Interactions, 28 (April), 137-164.

. (2003), 'The Nexus of Market Society, Liberal Preferences, and Democratic Peace: Interdisciplinary Theory and Evidence', International Studies Quarterly, 47 (4), 483-510

. (2005), 'Comparing New Theory with Prior Beliefs. Market Civilization and the Liberal Peace', Conflict Management and Peace Science, 22 (1), 63-77.

. (2009), 'The Social Market Roots of the Democratic Peace', International Security, 33 (4), 52-86.

Mousseau, M., H. Hegre and J.R. Oneal (2003), 'How the Wealth of Nations Conditions the Liberal Peace', European Journal of International Relations, 9 (4), 277-314.

North, Douglass (1990), Institutions, Institutional Change and Economic Performance, Cambridge, UK: Cambridge University Press.

Nozick, Robert. 1974. Anarchy, State, and Utopia. New York, NY: Basic Books.

Neary, H.M. (1997), 'A Comparison of Rent-Seeking Models and Economic Models of Conflict', Public Choice, 93 (3-4), 373-388.

Olson, Mancur (2000), Power and Prosperity: Outgrowing Communist and Capitalist Dictatorships. New York: Basic Books.

Oneal, J.R. (2003), 'Measuring Interdependence and Its Pacific Benefits', Journal of Peace Research, 40 (4), 721-725.

Oneal, J.R. and J.L. Ray (1997), 'New Tests of the Democratic Peace: Controlling for Economic Interdependence, 1950-85', Political Research Quarterly, 50 (4), 751-775.

Oneal, J.R. and B. Russett (1997), 'The Classical Liberals Were Right: Democracy, Interdependence, and Conflict, 1950-1985', International Studies Quarterly, 41 (2), 267-293.

(1999), 'The Kantian Peace: The Pacific Benefits of Democracy, Interdependence, and International Organizations, 1885-1992', World Politics, 52 (1), 1-37.

Oneal, J. R., F. H. Oneal, Z. Maoz, and B. Russett (1996), 'The Liberal Peace: Interdependence, Democracy, and International Conflict, 1950-85', Journal of Peace Research, 33 (1), 11-28.

Oneal, J.R., B. Russett, and M. L. Berbaum (2004), 'Causes of Peace: Democracy, Interdependence, and International Organizations, 1885-1992', International Studies Quarterly, 47 (3), 371-393. 
Owen, John M. (1997), Liberal Peace, Liberal War: American Politics and International Security, Ithaca, N.Y.: Cornell University Press.

Pape, R. A. (2005), Dying to Win: The Strategic Logic of Suicide Terrorism, New York: Random House.

Plaut, S. (2004), 'Misplaced Applications of Economic Theory to the Middle East', Public Choice, 118 (1-2), 11-24.

Polachek, S.W. (1980), 'Conflict and Trade', Journal of Conflict Resolution, 24 (1), 57-78.

- (1992), 'Conflict and Trade: An Economics Approach to Political International Interactions', in Walter Isard and Charles Anderton, eds, Economics of Arms Reduction and the Peace Process. Amsterdam: Elsevier Science, pp.89-120.

- (1999), 'Conflict and Trade: An Economics Approach to Political International Interactions', Peace Economics, Peace Science and Public Policy, 5 (2), Article 3.

Polachek, Solomon W. and Judith A. McDonald (1992), 'Strategic trade and the incentive for cooperation', in Manans Chatterji and Linda R. Forcey (eds), Disarmament, economic conversion, and management of peace, Westport, CT: Praeger, pp. 273-284.

Posner, D.N. (2004), 'The Political Salience of Cultural Difference: Why Chewas and Tumbukas Are Allies in Zambia and Adversaries in Malawi', American Political Science Review, 98 (4), $529-45$.

Powell, R. (2006), 'War as a Commitment Problem', International Organization, 60 (1), 169203

Raknerud, A. and H. Hegre (1997), 'The Hazard of War: Reassessing the Evidence for the Democratic Peace', Journal of Peace Research, 34 (4): 385-404.

Rapoport, David C. (1984), 'Fear and Trembling: Terrorism in Three Religious Traditions', American Political Science Review, 78 (3), 658-677.

Rashid, Ahmed (2000), Taliban: Militant Islam, Oil, and Fundamentalism in Central Asia. New Haven and New York: Yale Nota Bene.

Rauchhaus, R. (2009), 'Evaluating the Nuclear Peace Hypothesis', Journal of Conflict Resolution, 53 (2), 258-277.

Ray, J.L. (1993), 'Wars Between Democracies: Rare, or Nonexistent?', International Interactions, 18 (3), 251-276. 
Regan, P.M. and E.A. Henderson (2002), 'Democracy, Threats, and Political Repression in Developing Countries: Are Democracies Internally Less Violent?', Third World Quarterly, 23 (1), 119-136.

Regan, P.M., R.W. Frank, and D.H. Clark (2009), 'New Datasets on Political Institutions and Elections, 1972-2005’, Conflict Management and Peace Science, 26 (3), 286-304.

Reiter, Dan and Allan C. Stam (2002), Democracies at War, Princeton, N.J.: Princeton University Press.

Rocco, L. and Z. Ballo (2008), 'Provoking a Civil War', Public Choice, 134 (3-4), 347-366.

Rosato, S. (2003), 'The Flawed Logic of Democratic Peace Theory', American Political Science Review, 97 (4), 585-602. $\overline{467-472 .}$

. (2005), 'Explaining the Democratic Peace', American Political Science Review, 99 (3), . (2011), 'On the Democratic Peace', in Christopher J. Coyne and Rachel L. Mathers (eds.), The Handbook on the Political Economy of War, Cheltenham, UK: Edward Elgar Publishing, Inc., in press.

Rousseau, D.L., C. Gelpi, D. Reiter, and P.K. Huth (1996), 'Assessing the Dyadic Nature of the Democratic Peace, 1918-88’, American Political Science Review, 90 (3), 512-533.

Rummel, R.J. (1979), Understanding Conflict and War. Vol. 4, War, Power, Peace, Beverly Hills, CA: Sage. (1), 27-71.

(1983), 'Libertarianism and International Violence', Journal of Conflict Resolution 27 - (1985), 'Libertarian Propositions on Violence Within and Between Nations: A Test Against Published Research Results', Journal of Conflict Resolution, 29 (3), 419-455.

. (1995), 'Democracies ARE Less Warlike Than Other Regimes', European Journal of International Relations, 1 (4), 457-479.

Russett, Bruce (1993), Grasping the Democratic Peace: Principles for a Post-Cold War World, Princeton, N.J.: Princeton University Press.

. (1995), ‘And Yet It Moves', International Security, 19 (4), 164-177.

Sambanis, N. (2002), 'A Review of Recent Advances and Future Directions in the Quantitative Literature on Civil War', Defense and Peace Economics, 13 (3), 215-243. 
. (2004), 'What is Civil War?: Conceptual and Empirical Complexities of an Operational Definition', Journal of Conflict Resolution, 48 (6), 814-858.

Sandler, Todd and Keith Hartley (eds.) (2007), Handbook of Defense Economics: Volume 2, Defense in a Globalized World. Amsterdam: North-Holland (Elsevier).

Schultz, K.A. (1998), 'Domestic Opposition and Signaling in International Crises', American Political Science Review, 92 (4), 829-844.

Shavell, S. (1982), 'Suit and Settlement vs. Trial: A Theoretical Analysis under Alternative Methods for the Allocation of Legal Costs', Journal of Legal Studies, 11 (1): 55-81.

Shughart, William F. II (2006), ‘An Analytical History of Terrorism, 1945-2000', Public Choice, $128(1 / 2), 7-39$.

. (2011), 'Terrorism in rational choice perspective', in Christopher J. Coyne and Rachel L. Matehrs (eds.), The Handbook on the Political Economy of War, Cheltenham, UK: Edward Elgar Publishing, Inc., pp. 126-153.

Skaperdas, S. (1992), 'Cooperation, conflict, and power in the absence of property rights,' The American Economic Review, 82 (4), 720-739.

. (2002), 'Warlord Competition', Journal of Peace Research, 39 (4), 435-446.

. (2003), 'Restraining the Genuine Homo Economicus: Why the Economy Cannot Be Divorced From Its Governance', Economics \& Politics, 15 (2), 135-162.

Small, M. and J. D. Singer (1976), 'The War Proneness of Democratic Regimes, 1816-1965', The Jerusalem Journal of International Relations, 1 (1), 49-69.

Small, Melvin and J. David Singer (1982), Resort to Arms: International and Civil War, 18161980. Beverly Hills, CA: Sage.

Smith, Adam [1776] (2003), The Wealth of Nations. New York, NY: Bantam Dell. . [1759] (1976), The Theory of Moral Sentiments. Oxford: Clarendon Press.

Snyder, Jack L. (1991), Myths of Empire: Domestic Politics and International Ambition, Ithaca, N.Y.: Cornell University Press.

Sobek, D. (2010), 'Masters of their Domains: The Role of State Capacity in Civil Wars', Journal of Peace Research, 47 (3), 267-271. 
Souva, M. and B. Prins (2006), 'The Liberal Peace Revisited: The Role of Democracy, Dependence, and Development in Militarized Interstate Dispute Initiation, 1950-1999', International Interactions, 32 (2), 183-200.

Skocpol, Theda (1985), 'Brining the State Back In: Strategies of Analysis in Current Research', In P.B. Evans, D. Rueschemeyer, and T. Skocpol (eds.), Bringing the State Back In. New York: Cambridge University Press, pp. 3-43.

Stiglitz, Joseph and Linda Bilmes (2008), The Three Trillion Dollar War, New York, NY: W.W. Norton.

Tavares, J. and R. Wacziarg (2001), 'How democracy affects growth', European Economic Review, 45 (8), 1341-1378.

Thies, Cameron (2010), 'Of Rulers, Rebels, and Revenue: State Capacity, Civil War Onset, and Primary Commodities', Journal of Peace Research, 47 (3), 321-332.

Tir, J. and M. Jasinski (2008), 'Domestic-Level Diversionary Theory of War: Targeting Ethnic Minorities', Journal of Conflict Resolution, 52 (5), 641-664.

Tullock, Gordon (1967), 'The Welfare Costs of Tariffs, Monopolies, and Theft', Western Economic Journal, 5 (3), 224-232.

. (1980), 'Efficient Rent Seeking.' in, James M. Buchanan, Robert D. Tollison, and Gordon Tullock (eds.), Toward a Theory of the Rent Seeking Society, College Station, TX: Texas A\&M University Press, pp. 3-15.

. (2005), The Social Dilemma: Of Autocracy, Revolution, Coup D’Etat, and War. Fairfax, VA: Liberty Fund.

Usher, Dan (forthcoming), 'Bargaining unexplained', Public Choice.

Ward, M.D., R.M. Siverson, and X. Cao (2007), 'Disputes, Democracies, and Dependencies: A Reexamination of the Kantian Peace', American Journal of Political Science, 51 (3), 583-601.

Ward, M.D., B.D. Greenhill, and K.M. Bakke (2010), 'The Perils of Policy by P-Value: Predicting Civil Conflicts', Journal of Peace Research, 47 (4), 363-375.

Wantchekon, L. (1999), 'On the Nature of First Democratic Elections', Journal of Conflict Resolution, 43 (2), 245-258.

Weart, Spencer R. (1998), Never at War: Why Democracies Will Not Fight One Another, New Haven, CT: Yale University Press. 
Weede, E. (2004), 'The Diffusion of Prosperity and Peace by Globalization', The Independent Review, 9 (2), 165-186.

(2006), 'Economic Freedom and Development', CATO Journal, 26 (3), 511-524.

(2011), 'The Capitalist Peace', in Christopher J. Coyne and Rachel L. Mathers (eds.), The Handbook on the Political Economy of War, Cheltenham, UK: Edward Elgar Publishing, Inc., pp. 269-280.

Weeks, J. L. (2008), 'Autocratic Audience Costs: Regime Type and Signaling Resolve', International Organization, 62 (1), 35-64.

Weingast, B.R. (1997), 'The Political Foundations of Democracy and the Rule of Law', American Political Science Review, 91 (2), 245-263.

Werner, S. (2000), 'The Effect of Political Similarity on the Onset of Militarized Disputes, 18161985', Political Science Quarterly, 53 (2), 343-374.

Williamson, O.E. (2000), 'The New Institutional Economics: Taking Stock, Looking Ahead,' Journal of Economic Literature, 38 (3), 595-613.

Wood, E.J. (2003), 'Civil Wars: What We Don't Know', Global Governance, 9 (2), 247-260.

Xiang, J., X. Xu, and G. Keteku (2007), 'Power: The Missing Link in the Trade Conflict Relationship', Journal of Conflict Resolution, 51 (4), 646-663.

Yanagizawa, D. (2009), 'Propaganda and Conflict: Theory and Evidence from the Rwandan Genocide', Mimeo. 